\title{
Yerel Demokrasi ve Katılım: Türkiye ve İngiltere Üzerinden Bir İnceleme
}

\author{
Local Democracy and Participation: A Review on Turkey and England
}

\author{
Mehmet Akif ÖZER \\ Prof. Dr., Ankara Hacı Bayram Veli Üniversitesi, \\ İBF, Siyaset Bilimi ve Kamu Yönetimi Bölümü, \\ akifozer@yahoo.com \\ https://orcid.org/0000-0003-2220-2271
}

\section{Meryem KARTAL}

Doktora Öğr., Hitit Üniversitesi, Lisansüstü Eğitim Enstitüsüu, meryemkartal1995@gmail.com

https://orcid.org/0000-0003-3049-2053

\begin{tabular}{|c|c|}
\hline & ÖZET \\
\hline $\begin{array}{l}\text { Anahtar } \\
\text { Kelimeler: }\end{array}$ & $\begin{array}{l}\text { 21.yüzyıl dünyasında siyasi ve akademik platformlarda tartışılan konuların başında demokrasi, özerklik, } \\
\text { yerelleşme, katılım gibi kavramlar gelmektedir. Yerelde halkın ortak ihtiyaçlarını karşılayan kurumlar olarak } \\
\text { yapılan tartışmaların merkezinde yer almaktadır. Yerel yönetimler, yerel halkın karar alım süreçlerine }\end{array}$ \\
\hline Türkiye, & $\begin{array}{l}\text { katılımı açısından demokrasi ile ilişkilendirilmektedir. Bir ülkede demokrasinin yerleştirilmesi ve sağlam } \\
\text { temellere dayandırılması bakımından yerel yönetimler, oldukça önemlidir. Yerel halkın, siyasal bilinç }\end{array}$ \\
\hline Ingiltere, & $\begin{array}{l}\text { kazanmasl ve sorumluluk duygusu taşıması açısından önemli bir role sahiptir. Çallşmanın temel amacı, iki } \\
\text { ülkenin de yerel yönetimler yasal düzenlemeler ve uygulamalar boyutuyla incelenerek her iki ülkede yerel }\end{array}$ \\
\hline Yerel Yönetimler, & $\begin{array}{l}\text { demokrasi ile ilgili yapılan çalışmaların yerel demokrasiyi ne kadar yansıttı̆̆ ve yerel demokrasinin } \\
\text { geliștirilmesi için uygulanan katılım araçlarının etkinliğini ortaya koymaktır. Çalıșma Türkiye ve }\end{array}$ \\
\hline Yerel Demokrasi, & $\begin{array}{l}\text { Ingiltere'deki demokrasi ve katılımın tarihsel süreçteki teorik ve uygulama boyutunu karşılaştırmalı olarak } \\
\text { ortaya koyması açsından önem tasımakta, literatürdeki bosluğu tamamlamaktadır. Calısmanın amacına }\end{array}$ \\
\hline tllim & yönelik bilgiler Türkçe ve Ingilizce (birincil-ikincil) kaynak taraması yapılarak elde edilmiştir. \\
\hline
\end{tabular}

Keywords:

Turkey,

England,

Local Government,

Local Democracy,

Participation,

\section{ABSTRACT}

In the 21st century world, concepts such as democracy, autonomy, localization, participation are among the main topics discussed in political and academic platforms. It is at the center of the discussions as institutions that meet the common needs of the local people. Local governments are associated with democracy in terms of the participation of local people in decision-making processes. Local governments are very important for the establishment of democracy in a country and its foundation on a solid basis. It has an important role for the local people to gain political awareness and a sense of responsibility. One of the Anglo-Saxon countries has a tradition with the UK government to the European continent with the tradition of local democracy" çok anlaml durmuyor. The main purpose of the study is to examine the local governments in terms of legal regulations and practices in both countries and to demonstrate the extent to which the studies on local democracy in both countries reflect local democracy and the effectiveness of the participation tools applied for the development of local democracy. The study is important for comparatively demonstrating the theoretical and practical dimension of democracy and participation in Turkey and the UK in the historical process and completes the gap in the literature. Information for the purpose of the study was obtained by scanning Turkish and English (primary-secondary) sources.
\end{abstract}




\section{GIRISS}

21. yüzyılda dünya küresel ve yerel boyutta ekonomik, siyasal, sosyo-kültürel ve yönetsel açıdan büyük değişimlere uğramaktadır. Son yüzyıla damgasını vuran yeni yönetim anlayışında katııım kavramı demokrasinin vazgeçilmez bir unsuru olarak sürekli vurgulanmaktadır. Bununla birlikte uluslararası alanda kamuoyunun ortak bir noktada buluştuğu konulardan biri yerel yönetimler ve demokrasi arasında oldukça sıkı bir ilişkinin olduğudur. Günümüzün yükselen değerleri arasında bulunan yerel yönetimler, yerel demokrasi açısından vazgeçilmez unsurlardan biri olarak değerlendirilmekte ve ülkenin demokratikleşmesinde temel yapı taşı olarak nitelendirilmektedir. Modern çağda yerel demokrasi, yerel yönetim ve katılım kavramları birbiriyle yakından ilişkili kavramlardır.

Yerel demokrasi ve katılım konusunu Türkiye ve İngiltere örneğinde karşılaştırmalı olarak ele alan bu çalışmanın temel amacı, Türkiye ve İngiltere'de yerel yönetimler; yasal düzenlemeler ve uygulamalar boyutuyla incelenerek her iki ülkede yerel demokrasi ile ilgili yapılan çalışmaların yerel demokrasiyi ne kadar yansıttığı ve yerel demokrasinin geliştirilmesi için uygulanan katılım araçlarının neler olduğunu ortaya koyulmasıdır. Çalışmanın temel varsayımı tarihsel süreç içinde İngiltere'de yerel demokrasinin daha erken ortaya çıkması ve benimsenmesi yerel demokrasi uygulamalarını etkilemiş ve katılım uygulamalarının daha etkin bir şekilde hayata geçirilmesinde etkili olmuştur. Türkiye'de ise yerel demokrasinin İngiltere'ye göre daha geç benimsenmesi katılım uygulamalarının hem nitel hem de nicel olarak yeterince gelişmemesine yol açmıştır.

Çalışmanın amacına yönelik olarak her iki ülkenin yerel yönetimleri ve yerel demokrasiye yönelik uygulamaları tarihsel gelişim süreçleri içinde değerlendirilmiştir. Bu kapsamda da yerel halkın gözlem ve denetim gücünü de bünyesinde barındıran yerel katılım, makalede yerel demokrasinin güçlendirilmesi kapsamında incelenmiştir.

Çalışmanın temel hedefi, köklü bir yerel yönetim geleneğine sahip olan ve demokrasi açısından dünyada ön sıralarda yer alan ülkelerden biri olan İngiltere'nin yerel demokrasi konusundaki katılım mekanizmalarını ortaya koymak ve bu doğrultuda Türkiye'nin yerel demokrasi konusundaki mevcut durumunu tespit etmektir. Bu doğrultuda da Türkiye'de ve İngiltere' de yerel yönetim birimlerinin sağlamış olduğu katılım mekanizmaları açıklanarak yerel demokrasi ve katılım durumu yerel yönetimlerin tarihsel gelişim çizgisi ve buna paralel olarak yerel demokrasi ve katılımın geliştirilmesine yönelik yapılan düzenlenmeler ortaya konulmuştur. Çalışmada, Türkiye'de yerel yönetim birimlerinden ağıllıklı olarak belediyeler tarafindan uygulanan katılım mekanizmalarına yer verilmiştir.

Çalışmanın ikinci bölümünde Türkiye'de yerel demokrasinin ve katılımın gelişimi Cumhuriyet öncesi dönem ve Cumhuriyetten günümüze kadar olan süreçte yerel demokrasi ve katılım (1923-1960, 1961-1981, 1982-2008 ve 2008-günümüz) olmak üzere dört ana dönemde incelenmiştir. Çalı̧̧manın üçüncü bölümünde İngiltere'de yerel demokrasi ve katılımın gelişimi sanayi devrimi öncesi, 1832-1974 dönemi ve 1974 sonrası şeklinde tarihsel sınıflandırma yapılarak incelenmiş ve bölümün sonunda katılım mekanizmalarına yer verilmiştir. Çalışmanın son bölümünde ise Türkiye ve İngiltere'deki yerel demokrasi ve katılım anlayışı karşılaştırılmıştır. Bu bölümde karşılaştırma yapılırken iki ülkedeki yerel halkın katılımı, yerel yönetimlerin yasal dayanağı, idari vesayet denetimi ve son olarak yeni kamu yönetimi, yerelleşme ve yönetişim politikaları baz alınarak karşılaştırma yapılmıştır. Çalışma, Türkiye ve İngiltere'nin yerel yönetimlerinin tarihsel süreçte demokrasi ve katılımın tarihsel süreçte teorik ve uygulama boyutunu karşılaştırmalı olarak ortaya koyması açısından önem taşımakta, literatürdeki boşluğu tamamlamaktadır.

\section{TÜRKIYYE'DE YEREL DEMOKRASİ VE KATILIMIN GELIŞMESI}

Çalışmanın bu bölümünde Türkiye'de yerel demokrasi ve katılımın gelişimi tarihsel süreçte incelenecektir. Bu bağlamda cumhuriyet öncesi ve cumhuriyetten günümüze kadar şeklinde sinıflandırma yapılarak yerel demokrasi ve katılım incelenmiştir.

\subsection{Cumhuriyet Öncesi Dönemde Yerel Demokrasi ve Katılım}

Osmanlı İmparatorluğu'nun kuruluşu ile varlık kazanan ancak I. Beyazıt ve II. Mehmet ile bütün kurumlara yerleştirilmek istenen merkezi idare uygulaması 18. Yüzyıl başlarına kadar varlığını devam ettirmiştir. Yerel yönetimler, Osmanlı Devleti'nin 19. Yüzyılda gerçekleştirdiği Tanzimat ve Islahat hareketlerinin somut ürünleridir. Ortaylı (1985), Osmanlı Devleti'nim asıl amacının demokrasi ve yerel yönetim olmadı̆̆ını 
belirtmiştir. Bununla birlikte modern merkeziyetçi yönetim güçlendikçe Osmanlı devletinde modernlik bağlamında yerel yönetimlerin çekirdeğinin oluştuğunu ve yerel grupların yönetime katıldığını belirtmiştir (Ortayl1, 1985:21).

Cumhuriyet öncesi dönemde yerel yönetimler sisteminde, kentsel sorunların çözümü için tabanını halkın oluşturduğu bir demokratik yapılanma mevcut değildir. Tanzimat'ın ilanına kadar olan süreçte yerel hizmetler vakıflar tarafından yapılırken, belediye hizmetleri yönetsel ve yargısal görevleri elinde tutan kadılar yerine getirmektedir. İmar işleri dışında neredeyse tüm kentsel sorunlara bakan kadılar, toplumsal sorunların çözümünde yer alan ilk isimdir (Çukurçayır, 2012:175).

Tanzimat'ın ilanı ile birlikte ilk girişim vergi işlerinin yeniden düzenlemesiydi. Bu doğrultuda da iltizam sistemi kaldırılmış ve bunun yerine vergilerin toplanması amacıyla muhassıl olarak adlandırılan ve merkezden atanan memurlar görevlendirilmiştir. Muhassılın başkanlığında toplanan taşrada muhassıllık meclisleri kurulmuştur (Erbay ve Akgün, 2017:41-42). Ortayl1, muhassıll1k meclislerini Tanzimat ile birlikte gelen yerelleşme uğraşlarının ilk ve somut göstergeleri olarak değerlendirmiştir (Ortaylı, 1974:13).

Yerel yönetim kapsamında ilk belediyecilik deneyimi ise 1855 İstanbul Şehremaneti kurulması ile yaşanmıştır. Merkez tarafından atanan Şehremini, Şehremaneti'nin başında bulunmaktadır. Padişahın seçimi ve Padişah'ın onaylaması ile meclis oluşturulmuştur. Ancak Şehremaneti'nin başına atanan şehreminiler, hem yetenek hem de görüşleri açısından kentsel alanda o dönemde yaşanan değişimlere uyum sağlayamamış ve bu uygulama başarısızlıkla sonuçlanmıştır. Bunun sonucunda da 1856 yılında yabancı dil bilgisi olan Müslüman ve gayrimüslimlerin üye olduğu İntizam-1 Şehir Komisyonu kurulmuştur. Bu komisyon 1858 yılında onaylanan Nizamname-i Umumi sonrasında İstanbul'un 14 belediye dairesine bölünmesini kararlaştırmıştır. 1858 yılında gayrimüslimlerin ağırlıklı yaşadığı Beyoğlu ve Galata Semtlerinde Paris Belediyesi örnek alınarak mali özerkliğe sahip olan, ancak başkanı ve üyeleri merkezce atanan Altıncı Daire-i Belediye kurulmuştur. 1869 yılına gelindiğinde ise Dersaadet İdare-i Belediye Nizamnamesi yayımlanarak bu uygulama tüm İstanbul'da yaygınlaştııılmaya başlanmıştır. Bu nizamname kapsamında oluşturulan 14 dairenin üyeleri halk tarafindan seçilirken başkanları merkez tarafından atanmaktaydı (Koçak ve Ekşi, 2010:299).

1864 ve 1870 İdare-i Vilayet Nizamnameleri ile Osmanlı yönetim sisteminde yeni bir örgütlenme anlayışı ortaya çıkmıştır (Ortaylı, 1985:155). Bununla birlikte bu nizamnamelerle halkın yönetime katılımını sağlamak ve merkezin yükünün hafifletilmesi hedeflenmiştir. Ancak buna rağmen yapılan seçimlerdeki asıl belirleyici yine merkez olmuştur. Merkezi hükümet görevlilerin isimlerini belirleyerek alt meclislere sunmakta, merkezi hükümet memurlarının ağırlıklı olduğu kişilerce bu isimler seçilmekte ve son sözü de vali söylemektedir (Ortaylı, 1985:167-168). Yapılan seçimlerde din ayrımı gözetilmemekteydi. Fakat seçilen kişiler genellikle beldenin ekonomik ve sosyal yönden ileri gelen kişileriydi (Ortayl1, 1974:16).

1876 yılında yürürlüğe giren ve Osmanlı'nın ilk anayasası olarak kabul edilen Kanuni Esasi ile yerel yönetimler ilk kez anayasal metinde yer almıştır (Tortop vd., 2008:91). 1877 yılında Vilayet Belediye Kanunu'nun yayımlanması ile ülkedeki tüm kentlerde ve kasabalarda belediye meclisinin kurulmasına karar verilmiştir. Bu düzenleme sonrasında belediye idari bir varlık olmaktan ziyade artık bir tüzel kişilik kazanmıştır (Ortaylı, 2008:507). Bu kanun istisnalar hariç olmak üzere 1930 Belediye Kanunu'na kadar uygulanmıştır. 1912 y1lında yürürlüğe konulan bir kanunla "İstanbul Şehremaneti" tek belediye haline getirilmiş ve dokuz şubeye ayrılmıştır. Her şubeye merkez tarafından atanan bir müdürle yeniden merkeziyetçilik anlayışına dönülmüştür (Parlak ve Ökmen, 2015:168).

1877 Dersaadet ve Vilayet Belediye Kanunları ile belediyenin tüzel kişilik kazanmasına rağmen Türk Belediyeciliği'ne demokrasi ve yerel demokrasiyi kazandırmamıştır. Kanun ile merkezi yönetim tarafından yapılamayan hizmetleri yerine getiren ve harap olan kentlerin yeniden imar edilmesini sağlayacak yeni bir kurum oluşturulmuştur. Osmanlı bürokrasinin merkezi idare dışındaki güçlere güvensizliği ve uzun süreli savaşlar sonucu ülkenin iktisadi ve sosyal yapısı, yerel demokrasinin gelişmesini engellemiş̧tir (Görmez, 1997:94).

İkinci meşrutiyet döneminde ise yerel demokrasiyi savunup, il kurulları ile yönetsel ve akçal kontrolün halkın elinde olması gerektiğini savunan bazı düşünürler olmuştur. Bunların başında gelen Prens Sebahattin, toplumsal bir yapının oluşması için yerel yönetimleri zorunlu olarak görmüş, onun görüşleri, bireysel gelişim ve adem-i merkeziyet ilkelerine dayanmıştır. Prens Sebahattin, merkezi hükümetin yetkilerinin azaltılarak, imparatorluk bünyesindeki farklı unsurların yönetime katılma yetkilerinin genişletilmesi gerektiğini vurgulamıştır (Sebahattin, 1999:34-37). Cumhuriyet öncesindeki yerel demokrasi ve katılım konusundaki gelişmeler ve yapılan düzenlemeler bu şekilde anlatıldıktan sonra cumhuriyetten günümüze kadar olan gelişmeleri detaylı bir şekilde inceleyebiliriz. 


\subsection{Cumhuriyetten Günümüze Türkiye'de Yerel Demokrasi ve Katılım}

Çalışmanın bu kısmında yerel demokrasi ve katılım konusundaki gelişmeler "1923-1960 dönemi”, "1961-1981 dönemi”, "1982-2000 dönemi”, "2000 sonrası dönem" şeklinde sınıflandırma yapılarak incelenmiştir.

\subsubsection{3-1960 Dönemi Gelişmeleri}

Osmanlı'dan devralınan miras ile birlikte Cumhuriyetin kuruluş döneminde il özel idarelerine yönelik olarak herhangi bir yeni kanun çıkarılmamış, imparatorluk döneminde oluşturulan 1913 tarihli geçici kanun 2000'li yıllara kadar il özel idarelerinin düzenlendiği kanun olarak varlığını devam ettirmiştir (Beyazyıldız, 2010:85).

1921 Anayasası, yerel yönetimler ve yerel demokrasinin gelişimi açısından "eşi bulunmaz bir statü” getirmiştir (Ortaylı, 1985:207). Bu anayasa ile yerel yönetimler merkezi yönetin dışına çıkan bir nitelik taşımamış olsa da âdem-i merkeziyetçiliğin ağırlıklı olduğu düşüncelere yer verildiği söylenebilir (Önen ve Reyhan, 2011:454456). Kanunun 11. maddesinde vilayetler, yerel düzeyde tüzel kişilik taşıyan ve özerkliğe sahip kuruluşlar olarak kabul edilmiştir. Sağlık, eğitim, ekonomi ve tarım gibi konularda vilayet meclisi yetkilendirilmiş, yerel konularda özerklik kabul edilmiştir (Erbay ve Akgün, 2017:70). 1921 Anayasası ile 1876 Anayasası'ndan farklı olarak vilayet ve nahiyelere özerk bir statü ve tüzel kişilik tanınmıştır (Keleş, 2014:163).

1924 Anayasası'nın 90. maddesinde vilayetlerin, şehir, kasaba ve köylerin tüzel kişiliğe sahip olduğu belirtilmiş 91.madde de vilayetlerin yetki genişliği ve görev ayrımı ilkesine göre idare edildiği belirtilmiştir. Yani 1924 Anayasası'nda da 1876 Anayasası'nda kabul edilen görev ayrımı ve yetki genişliği ilkesi benimsenmiştir (Keleş, 2014:164). Ayrıca 1924 Anayasası ile Ankara için özel bir belediye kurulması kabul edilmiş ve 1924 yılında çıkarılan yasa sonrasında Ankara Şehremaneti kurulmuştur. 1924 yılında çıkarılan 442 sayılı Köy Kanunu ile köyde yapılacak hizmetlere köylünün akçal ve işgücü açısından katılımının zorunlu olduğu belirtilmiştir (Çukurçayır, 2012:184).

1930 yılında 1580 sayılı Belediye Kanunu çıkarılmıştır. Bu kanunun yürürlüğe girmesi ile birlikte Dersaadet Belediye Kanunu ve Vilayet Belediye Kanunu olarak adlandırılan 1877 tarihli yasal düzenlemeleri ve 1924 tarihli Ankara Şehramaneti yürürlükten kaldırılmıştır. 1580 sayılı yasa daha önceki yasal düzenlemelerden farklı olarak bazı istisnalar hariç olmak üzere belediye başkanının meclis üyelerince kendi arasından seçilmesi ya da seçilme şartını taşıyan dışarıdan bir kişinin seçilmesine imkân vermesi de demokrasi açısından önemli katkılar sunmuştur (Eryılmaz, 2002:8). 1960'lı yıllara kadar olan gelişmeler açıklandıktan sonra 1980'li yıllara kadar olan gelişmeleri inceleyebiliriz.

\subsubsection{1-1981 Dönemi Gelişmeleri}

1961 Anayasası, yerel yönetimlere yönelik ayrıntılı düzenlemelere yer vermiştir. Yerel yönetimlere daha faza özerklik tanınmış, güçlü bir yerel yönetim sisteminin oluşturulması hedeflenmiştir (Eryılmaz, 2002:17). 1961 Anayasası'nda merkezden yönetim ve yerinden yönetim şeklinde idarenin esasları düzenlenmiştir. Anayasanın 166. maddesinde yerel yönetimler (mahalli idareler); "il, belediye ve köy halkının mahalli müşserek ihtiyaçlarını karşılayan ve genel karar organları halk tarafindan seçilen kamu tüzel kişileridir", şeklinde tanımlamaktadır (Beyazyıldız, 2010:86-87). Bu dönemdeki en önemli gelişmelerden biri de belediyelerin yönetim yapısında yaşanan değişimdir. Belediye başkanları 1963 yılına kadar meclis içinde seçilmiş ve vesayet organları tarafından onaylanmıştır. $\mathrm{Bu}$ tarihten sonra ise belediye başkanlarının doğrudan halk tarafından seçilmesine karar verilmiştir (Erbay ve Akgün, 2017:73).

1973 yılında yapılan seçimlerle büyük kentlerde genellikle belediye başkanlıkları ve meclis üyeliklerinin büyük bir bölümü CHP'li adaylar tarafından doldurulmuştur. Merkezi yönetimden farklı bir partinin seçimlerde ön plana çıkması ile merkez-yerel arasındaki çatışmalar da artmıştır. Bu dönemde dikkat çeken demokratik belediyecilik anlayışının ilkeleri daha özerk, daha demokratik, daha katılımcı gibi değerlere dayanmıştır (Koçak ve Ekşi, 2010:302). 1960'lardan 1980'lere kadar olan gelişmeleri inceledikten sonra yerel demokrasi ve katılım konusunda en somut adımların atılmaya başladığı 1982-2000 dönemini inceleyebiliriz. 


\subsubsection{2-2004 Dönemi Gelişmeleri}

1980'li yıllardan itibaren Türkiye'de yeni bir belediyecilik anlayışı ortaya çıkmış ve bu kapsamda da artan kentleşmeye bağlı olarak plansız ve düzensiz yerleşimler ortaya çıkmıştır. Denetim dışında kalan bu alanların tekrar denetim altına alınması, plan bütünlüğünün sağlanması, küçük birimler arasında işbirliğinin oluşturulması için büyükşehir yönetimlerine yönelik özel model arayışına girilmiştir (Keleş, 2014:326). Bu kapsamda 1980 yılında büyükşehirlere özgü yeni yönetim modelinin oluşturulmasına imkân tanıyan yasa 3030 çıkarılmıştır. Bu yasa kapsamında da başta İstanbul, İzmir ve Ankara'da büyükşehir yönetim modeli uygulanmıştır (Erbay ve Akgün, 2017:75).

Büyükşehir ilçe belediyeleri, büyükşehir belediyelerinden farklı olarak iki farklı vesayet denetimine tabi kılınmıştır. Bu doğrultuda büyükşehir belediye başkanı, ilçe belediyeleri tarafından sunulan hizmetler üzerinde denetim ve gözetim yetkisine sahiptir. Bununla birlikte ilçe belediye meclisleri arasında çıkan uyuşmazlıklarda da düzenleyici ve yol gösterici olarak büyükşehir belediyeleri doğrudan yetki sahibidir. Bu durum ise yerel demokrasi ve özerklik açısından aykırılık taşımaktadır. Yine büyükşehir belediyesinin genel sekreterinin İçişleri Bakanı'nın onayı ile atanması, büyükşehir belediye meclisi tarafından alınan kararların belediye başkanının gözden geçirmeye yönelik hak sahibi olması gibi hususların aslında yerel özerklik ve demokrasi ile bağdaştırılamayacağı belirtilmektedir (Beyazyıldız, 2010:94). Türkiye'de bu dönemde öne çıkan yerel katılım ve demokrasi araçları şunlardır;

- Gelecek Atölyeleri: Kentsel alandaki geleceğe yönelik her türlü toplumsal ve kentsel sorun ve konunun ele alınarak değerlendirildiği etkili yöntemlerden biridir. Bir yöneticinin başkanlığında çalışan bu atölyelerde dilek, şikâyet, umut ve beklentiler belirtilerek değerlendirilmektedir (Yerel Yönetimler Özel İhtisas Komisyonu Raporu, 2001:119). Gelecek atölyeleri, tek bir kentsel grup yerine birden çok farklı grupların bir araya gelerek mevcut olan sorunların tespit edilip nasıl çözümlenebileceğinin tartışıldığ iletişim ve etkileşime dayalı bir yöntemdir (Coşkun ve Sezer, 2004:284).

- Halk Günleri: Belediye başkanları tarafindan haftanın veya ayın belli günlerinde düzenlenmektedir. Halkın sorunlarını, beklentilerini ve isteklerini belediye başkanı başta olmak üzere kent yöneticileri ile yüz yüze görüşmesi amacıyla düzenlenmektedir. Halk günleri ile kent halkı, sorunlarını doğrudan anlatma imkânı elde etmektedir. 1990'lı yıllardan itibaren yaygın olarak düzenlenmeye başlayan halk günlerinde yapılan görüşmelerinin genellikle yeterli bilgilendirmeye dayanmaması, yardım ağırlıklı olması, kurumsallaşmaya yönelik bazı çekincelerin olması kent sakinlerinin katılımını olumsuz etkilemiştir (Güven ve Alan, 2019:53). Bununla birlikte özellikle seçim atmosferlerinin yaşandığ dönemlerde bu uygulamanın daha da etkin kullanılmaları söz konusu olmaktadır. Mahalle/köy dernekleri, amatör spor kulüpleri, semt etkinlikleri, meslek odası toplantıları, STK ve diğer gönüllü organizasyonlar ile eğlence etkinlikleri bile siyasi aktörler tarafindan halk günleri araçlarına dönüştürülebilmektedir.

-Dilekçe: En önemli bilgilendirme kaynağı olan dilekçe, ülkemizde anayasal haklardan biridir. Dilekçe, bireysel çıkarların korunması, kamusal sorunlar ve kamusal çıkarların korunması amacıyla son yıllarda yaygınlık kazanmıştır. 1982 Anayasası'nın 74. maddesinde "Vatandaşlar ve karşıllıklılık esası gözetilmek kaydryla Türkiye'de ikamet eden yabancılar, kendileriyle veya kamu ile ilgili dilek ve şikâyetleri hakkında, yetkili makamlara ve Türkiye Büyük Millet Meclisine yazı ile başvurma hakkına sahiptir. Kendileriyle ilgili başvurmaların sonucu, gecikmeksizin dilekçe sahiplerine yazılı olarak bildirilir", hükmüne yer verilmiştir. Böylece vatandaşlara, kamu kurum ve kuruluşlarına dilek ve şikâyet etme hakkı verilmiştir. Dilekçe, yönetime katılma açısından hem masrafsız hem de kolay olması nedeniyle en sık kullanılan yöntemlerden biridir. Dilekçe, belediyeler için önemli bir bilgi edinme kaynağıdır. Ancak bu yöntemin başarılı olması, dilekçe hakkını kullanan yurttaşlara yönetimin olumlu yaklaşması gerekmektedir. Çünkü dilekçede yer alan şikâyetler dikkate alınmıyor, istekler önemsenmiyor ise yerel katılımın gerçekleştirilmesi oldukça zordur (Güven ve Alan, 2019:53). Bununla birlikte talep ve şikâyet içerikli dilekçelerin "Bilgi Edinme Hakkı Kanunu" kapsamında belirli sürelerde cevaplanması gerektiği ve cevaplanmaması durumunda da talebin/isteğin reddedilmiş sayılarak adli/idari işlemlere basamak oluşturacağı için etkinliği oldukça fazladır. Dilekçeler resmi evrak olma özelliğine sahiptirler.

- Beyaz Masa: Türkiye'de ilk kez 1994 yılında İstanbul Büyükşehir Belediyesi tarafından kurulmuş (Aksoy, 2006:58) olup; sosyal belediyecilik anlayışının bir yansıması olarak diğer belediyeler tarafından 
ÖZER, Mehmet Akif ve KARTAL, Meryem - Yerel Demokrasi ve Katılım: Türkiye ve İngiltere Üzerinden Bir İnceleme

da aynı ya da benzer adlar ${ }^{1}$ altında uygulanmaya başlanmıştır. Beyaz masa uygulamasının temel amacı, vatandaşların karmaşık bürokratik işlemlerden kurtararak onların çeşitli istek, dilek ve beklentilerini tek bir noktadan ilgili birime ulaştırmaktır. Böylece vatandaşlar, yalnızca tek bir ofise müracaat etmekte, sorunlar ilk olarak bu ofiste yer alan personeller tarafindan giderilmeye çalışılmakta ve vatandaşlara işlemlerle ilgili gerekli bilgiler verilmektedir. Yerel halk ile belediye arasında bir iletişim aracı olan beyaz masa, halkın sorunlarının üst mercilere gitmeksizin çözülebileceği güvencesi vermesi ile belediye çalışmalarına katılım yolu açılmış olacaktır. Ayrıca vatandaşın sorun ve şikâyetleri ile ilgilenildiği zaman vatandaş hem kent ile ilgili konulara daha duyarlı olacak, hem de karar alma sürecine katılım sağlayacaktır (Güven ve Alan, 2019:57). Bağlı oldukları müdürlükler içerisinde "servis, merkez, birim, büro, şeflik vb." adlar altında teşkilatlandırılan (Uyar ve Mecek, 2016:151) beyaz masa birimleri, kendisine ulaşan tüm istek, talep, görüş ve şikâyetleri kayıt altına alarak değerlendiren ve konuyla ilgili çözüm üreterek, elde edilen veriler doğrultusunda belediye kaynakların daha etkin verimli kullanılmasına hizmet eden halkla ilişkiler birimidir (İBB, 2010:1).

- Yerel Referandum: Avrupa Yerel Yönetimler Özerklik Şartı'nda referandum, yerel yönetimlerin sınırlarının değiştirilmesi açısından yapılması hükmü yer almaktadır. Avrupa Kentsel Şartı'nda da beldenin geleceğine yönelik olarak önemli konularda yerel halkın bilgilendirilmesi, fikirlerinin alınması ve yerel halkın karar alım süreçlerine aktif katılımının sağlanması belirtilmiştir. Ülkemizde yerel düzeyde referandum modeli köylerin belediyeye dönüşmesi ile belediyelerde "birleşme" ve "katılma" süreçlerinde uygulanmaktadır. Türkiye'de yerel yönetimlerin halkoyuna sundukları hizmetlerin sayısı çok azdır. Bunun nedenlerinin, yöneticilerin yerel iktidarı paylaşmama isteği ile birlikte bu yöntemin belli bir zaman, uzmanlık ve maddiyat gerektirmesi olduğu söylenilebilir. Tüm bunlara rağmen özellikle küçük şehirlerdeki yönetenlerin, her kararı olmasa da önemli yerel kararları halk oylamasına sunması doğrudan demokrasiyi sağlamak için bir yol olabilir (Yaman ve Küçükşen, 2011:250). Seçim havasında gerçekleşmesi, manüplasyona açık olması, büyük maliyetler getirmesi ve geniş zaman dilimli olması gibi nedenler ile eleştirilen bir yöntem olsa da demokrasi ve katılım kültürünün gelişmesi açısından oldukça önemli bir araçtır (Yaylı ve Pustu, 2008:139).

- Semt Dayanışma Merkezleri (SEDAM): SEDAM, belediyenin bir mahalle bürosu gibi çalışıp, birçok işlevi yerine getiren birim olarak etkinlikte bulunma özelliğine sahiptir. Bu birimler, belediye ile yerel halk arasındaki iletişimin sağlanmasında önemli bir işlevi yerine getirmektedir. Bu birimlerin en güzel örneği yine Bursa Büyükşehir Belediyesi'nde görülmekte ve 1994'ten beri bu birimler kentteki demokrasi ve katılım bilincinin artmasına yönelik önemli işlevler üstlenmektedir (Çukurçayır, 2012:206).

- Yuvarlık Masa Toplantıları: Yereldeki tüm halkın temsiline imkân tanıyan yuvarlak masa toplantılarının katılımcıları ağırlıklı olarak bilim insanları ve sorun alanlarına göre uzmanlardan oluşmaktadır. Forum olarak da adlandırılan bu toplantıların temel amacı, ihtiyaç duyulan konularda bilimsel/uzman görüşlerinin ortaya konulması, bunların karar alıcılara objektif bir şekilde aktarılmasıdır (Çukurçayır, 2012:151). Diğer katılım araçlarına göre katılımcı sayısı daha az olmasına rağmen, alanında uzman kişilerden oluşması nedeniyle daha desteklenebilir ve objektif bir görüş olma niteliğine sahiptir. Toplantı sonucu alınan kararların sosyal grupları "temsil" etme yeteneğine sahip olmasının yanı sıra taşıdı̆̆ bilimsellik nedeniyle "güvenilir" olma niteliği de bulunmaktadır.

- Halk Toplantılart: Bu katılım mekanizmasını hemen hemen tüm yerel yönetimler kullanmaktadır (Çukurçayır, 2012:155). Yerel halkın yönetimin eylem ve işlemleri konusunda bilgilendirildiği toplantılarda uzmanlar, yöneticiler ve halk kamu politikaları konusunda tartışıp karara varmaktadır. Yerel halk ve vatandaş arasındaki bilgi akışının sağlandığı bu toplantılarda vatandaşların önerilerinin dikkate alınması yerel demokrasi açısından önemli katkılar sunmaktadır (Yerel Yönetimler Özel İhtisas Komisyonu Raporu, 2001:117). Yapılan bilgilendirmeler ve istişareler neticesinde halk toplantısında uygulanabilir nitelikte kararların alınması ve uygulanması ile denetim mekanizmalarının kurulması hiç şüphesiz ileri düzeyde bir katılım mekanizmasının hayata geçmesine katkı sağlayacaktır (Yaylı ve Pustu, 2008:139). Ancak Türkiye' de halk toplantılarında alınan kararlar henüz bağlayıcı nitelikte değil, yalnızca danışma (istişari) niteliktedir (Yalçındağ, 1996:141).

1 Örneğin Tuzla (İstanbul), Erzurum, Afyonkarahisar, Düzce, Elazı̆̆g, Çaycuma (Zonguldak), Turhal (Tokat) gibi birçok belediyeler benzer birimleri için "Beyaz Masa" adını tercih ederken; Keçiören (Ankara) Belediyesi Ak Masa, Eyyübiye (Şanlıurfa) Belediyesi Türkuaz Masa, Muratpaşa (Antalya) Belediyesi Turunç Masa ve Ankara Büyükşehir Belediyesi de Mavi Masa adını kullanmayı tercih etmişlerdir (Uyar ve Mecek, 2016:151). 
- Halk Günleri: Türkiye'de belediyeler tarafından gerçekleştirilen önemli katılım mekanizmalarından biri de halk günleridir. Birçok belediye tarafından düzenlenen halk günlerinde belediye başkanları, vatandaşlar tarafından dile getirilen sorunlara yönelik kapsamlı çözüm yolları aramaktadır. Düzce Halk Günü, Denizli Halk Günleri, Antalya Muratpaşa Halk Günleri, Akşehir Halk Günü, İstanbul Fatih Halk Günü ve İstanbul Sancaktepe Halk Günü gibi birçok yapılan toplantı halk günlerine örnek gösterilebilir. Halk günlerinin yapılması önemli olmakla birlikte, halktan alınan geri dönüşlere ne kadar cevap verildiği de bir o kadar önemlidir. Halkın istek, dilek ve şikâyetlerine cevap alamaması durumunda katılımın düzeyi düşecektir (Yaman ve Küçükşen, 2018:252).

- Meclis Toplantılarına Katılım: Yerel halk belediye meclislerinin toplantılarına katılarak yerel düzeydeki kamu politikaları konusunda bilgi sahibi olurken aynı zamanda kendi istek, beklenti ve taleplerini açıklama imkânı elde etmektedir. Bireyler ayrıca kendi yaşam alanlarına yönelik alınabilecek kararları etkileme olanağına sahiptir (Önez, 2006:52). Ancak, bu aracın etkin olabilmesi için toplantı zaman ve gündemlerinin kent halkına etkin kanallar üzerinden duyurulması ve halk katılımının sağlanması gerekmektedir. Türkiye'de belediye meclis toplantılarını yerel halkın katılım düzeyini ölçmek amacıyla yapılan araştırma sonucunda ülkedeki belediyelerin yaklaşı $\% 75$ inde belde halkı meclis toplantılarına katılmamaktadır. Bununla birlikte katılımın olduğu belediyelerde ise katılan kişi sayısının oldukça az olduğu saptanmıştır. Toplumsal ve mekânsal açıdan halka yakın olduğu ileri sürülen daha küçük ölçekli belediyelerde ise katılım oranının daha da düşük olduğu saptanmıştır (Çiftçi, 1999:246). Yerel halkın toplantıları sadece izleyici olarak (pasif suje) katılması, aktif bir rol alamaması bu aracın etkinliğini azaltan bir diğer faktördür. Ancak bu toplantıların son dönemlerde canlı yayınlar ile sosyal medyadan halka açık hale getirilmesi, kamuoyu denetiminin gelişmesi açısından önemli bir adım olmuştur.

- Çevre Sorunları ve Halk Katılımı -Yerel Gündem 21: 1992 yılında BM tarafından Rio'da düzenlenen Çevre ve Kalkınama Konferansı'nın bir ürünü olarak kabul edilen Gündem 21, yerel yönetimlerin karar alırken yerel halk ile işbirliği içinde olmaları esasına dayanmaktadır (Emrealp, 2005:16). Ülkemizde de Yerel Gündem 21 faaliyetleri ilk kez 1997 yılının sonlarında Uluslararası Yerel Yönetimler Birliği ve Doğu Akdeniz ve Ortadoğu Bölge Teşkilatı'nın toplanması sonrasında kabul edilen “Türkiye'de Yerel Gündem 21 'lerin Teşviki ve Geliştirilmesi" projesiyle başlamıştır (Bozkurt, 2014:234). Türkiye'de Yerel Gündem 21'in uygulanması konusunda bir eğilim olmasına rağmen, bu oldukça sınırlıdır. Bu uygulamanın en güzel örneği, Bursa Anakent Belediyesi tarafından kurulan Yerel Gündem 21 Çevre Konseyi'dir. Yerel Gündem 21, başarılı uygulama örneklerine rağmen 2000'li yılların başlarında kent konseylerinin oluşumu ile işlerliğini kaybetmiştir (Yaman ve Küçükşen, 2018:252). 2000'li yıllara kadar olan gelişmeleri bu şekilde açıkladıktan sonra yerel demokrasi ve katılım mekanizmalarının geliştirilmeye ve güçlendirilmeye başlandığ 2000 ’lerden günümüze kadar olan gelişmeleri inceleyebiliriz.

\subsubsection{4'den Günümüze Kadar Olan Süreçteki Gelişmeler}

Yerel yönetimlere yönelik yapılan reformlar, 2004 yılında 5216 sayılı Büyükşsehir Belediyesi Kanunu, 2005 yılında 5393 sayılı Belediye Kanunu ve 5302 sayılı İl Özel İdaresi Kanunu ile başlatılmıştır. Yapılan yasal düzenlenmelerle yerel yönetimler güçlendirilmiş, halk katılımı ve özerklik ilkelerinin ön planda olduğu bir belediyecilik anlayışı yerleştirilmeye çalışılmıştır. Bununla birlikte 2008 yılında çıkarılan 5747 sayılı “Büyükşehir Belediyesi Sinırları İçerisinde İlçe Kurulması Hakkında Kanun'la büyükşehir olan alanlarda alt kademe belediyeleri, belde belediyelerinin varlığına son verilerek bazı yeni ilçeler kurularak yalnızca alt kademe belediyesi olarak ilçe belediyeler, statüsüne yer verilmiştir. Her iki kanunla da daha demokratik ve katılımcı bir yerel yönetim oluşturulmaya çalışılmıştır (Koçak ve Ekşi, 2010:303-304). 2000'li yıllardan itibaren daha katılımcı ve demokratik bir yerel yönetim anlayışının oluşturulmasına yönelik yapılan düzenlemeler şunlardır;

- Kent Konseyleri: Belediye Kanununun 76. maddesinde kent konseyleri; kent vizyonunun ve kentlilik bilincinin geliştirilmesi, sürdürülebilir kalkınma, sosyal yardımlaşma ve dayanışma, kentin hak ve hukukunun korunması, hesap sorma ve hesap verebilirlik, yerinden yönetim, katılım, çevreye duyarlılık gibi ilkelerin hayata geçirilmesi amacıyla faaliyette bulunmaktadır. Kent konseyleri; meslek kuruluşları, sivil toplum örgütleri, siyasi muhtarlar, üniversite ve siyasi partilerin temsilcileri gibi farklı aktörlerin katılımı ve desteği ile faaliyetleri gerçekleştirmektedir (5393 sayılı Kanun, md.76) şeklinde tanımlanmıştır. Kent konseyleri, kamu kurumu niteliğindeki meslek kuruluşlarının, sendikaların, noterlerin, varsa üniversitelerin, ilgili sivil toplum kuruluşlarının ve mahalle muhtarlarının temsilcileri ile diğer ilgililerin katılımıyla oluşan bir yapıdır. Kent Konseyinde alınan kararlar "görüş" niteliğindedir ve 
ÖZER, Mehmet Akif ve KARTAL, Meryem - Yerel Demokrasi ve Katılım: Türkiye ve İngiltere Üzerinden Bir İnceleme

bağlayıcılığı yoktur. Bununla birlikte belediye meclisi bu görüşleri ilk meclis toplantısında değerlendirmek ve sonucu kent konseyine bildirmek zorundadır. Yerel katılım açısından en etkili mekanizmalardan biri olan kent konseyleri, yerel kararların alınmasında etkili olabilmektedir. Fakat hem yapısal hem de yasal hem de siyasi kültürden kaynaklanan sorunlardan dolayı kent konseylerin etkililiği ve yaygınlığı yeteri düzeyde değildir. Ülkemizde bütün belediyelerde kurulması gereken kent konseylerinin, bazı belediyelerde yer alamaması içselleştirme konusunda bazı sıkıntıların olduğunu göstermektedir. Bu doğrultuda kent konseylerinin yerel demokrasinin iyi bir aracı olması için yasalyapısal anlamda revizyona ve toplumun bilgi, sorumluluk ve katılım düşüncesinin değişimine ihtiyaç duymaktadır (Yaman ve Küçükşen, 2018:255). Kent konseylerinin kararlarının tavsiye niteliğinde olması, öneriden öteye geçememesi ve herhangi bir yaptırımının olmaması kent konseylerinin etkinliğine ve çalışmalarına gölge düşürmektedir. Bununla birlikte kent konseylerinin hem bütçesinin, hem de harcama yetkisinin olmaması ve belediyenin bütçesinden yararlanması faaliyet alanını sınırlandırmaktadır (Emrealp, 2010:15).

- Gönüllü ve Dayanışmacı Örgütlenme: 5393 Sayılı Belediye Kanunu'nun 77. maddesinde gönüllü ve dayanışmacı örgütlenme, belediyelerin; kente yönelik olarak eğitim, çevre, sağlık, spor, kütüphane, trafik, kadınlara, çocuklara, yoksul ve engellilere yönelik hizmetleri gerçekleştirirken beldede yardım ve dayanışmanın sağlanması, hizmetlerin etkin ve verimli yürütmek amacıyla kentte gönüllü bireylerin katılımına yönelik faaliyet ve programlar uygulamasına imkân tanıması olarak tanımlanmıştır (5393 sayılı Kanun, md.77) şeklinde bir maddeye yer verilmiştir.

- Hemşehri Hukuku: 5393 sayılı Belediye Kanunu'nun 13. maddesinde 1580 sayılı belediye kanunundan farklı olarak herkes doğduğu şehrin değil, ikamet ettiği şehrin hemşehrisi olarak kabul edilmiştir. Bu doğrultuda da hemşehrilerin, belediyelerin kentteki karar alım ve uygulama sürecine katılma, yardımlarından yararlanma ve faaliyetleri hakkında bilgilenme hakkına sahip olduğu belirtilmiştir. Belediyeler, hemşehrileri arasındaki sosyo-kültürel ilişkilerin geliştirilmesine yönelik çalışmalar yapmaktadır. Belediyelerin bu çalışmaları ise sendikalar, üniversiteler, kamu kurumu niteliğindeki meslek kuruluşları, sivil toplum örgütleri gibi farklı aktörlerin katılımı ile gerçekleştirmektedir (5393 sayılı Kanun, md.13) şeklinde bir tanımlama yapılmıştır.

- Ihtisas Komisyonlart: 5393 sayılı Belediye Kanunu'nun 24. maddesinde, belediye meclisi, kendi üyeleri arasından en az üç en fazla beş kişiden oluşan bir ihtisas komisyonunun kurulacağ belirtilmiştir. Kentteki mahalle muhtarları, kamu kurumu niteliğindeki meslek kuruluşları, sendikalar, üniversiteler, ildeki kamu kurumu amirleri gibi faklı aktörlerin oy hakkı olmaksızın kendi görev ve faaliyet alanına yönelik konuların görüşüldüğü ihtisas komisyonu toplantılarına katılabileceği belirtilmiştir (5393 sayılı Kanun, md.24).

- 12 Kasım 2012 tarih ve 6360 sayılı On Üç İlde Büyükşehir Belediyesi ve 26 İlçe Kurulması ile Bazı Kanun ve Kanun Hükmünde Kararnamelerde Değişiklik Yapılmasına Dair Kanun: Bu kanun ile büyükşehir olan illerdeki ilçelerin mülki sınırları dâhilinde kalan köy ve belde belediyelerinin tüzel kişiliğine son verilmiştir. Köyler mahalle olurken, bu illerin bucak teşkilatları ve il özel idareleri kaldırılmıştır. 2012 yılında yapılan bu yasal düzenlemenin demokratik meşrutiyet eksikliği taşıdığını, ilgili taraflarla yerel toplulukların görüşlerinin alınmadığını ve bilimsel bir hesap yapılmadan bu kararın alındığını vurgulanmaktadır (Çukurçayır, 2012:20). Ayrıca 6360 Sayılı kanunun ile gelen bu köklü değişimlerin AB'nin "Subsidiarity" (hizmette halka yakınlık) ilkesine de aykırı olduğunu vurgulamak gerekir. Subsidiarity ilkesine göre yerel topluluklar kendilerine en yakın olan yerel idare birimlerinden hizmet almalıdır. Yerel halkın, kilometrelerce yol giderek, büyükşehirlerden hizmet istemesi maalesef bu ilkeye uymamaktadır. Yerel halkın, siyasete ve yönetime katılma imkânlarının ve yerel birimlere yakınlığının azalması da söz konusudur. 2000'li yıllardan itibaren katılım mekanizmaları güçlendirilmeye çalışılırken bu yasal düzenleme ile katılım daha da zorlaşmıştır. Her ne kadar bu kanunla merkezi idarenin güçlendiği izlenimi verilmiş olsa da büyükşehir belediyelerinin sınırlarının il sınırı olarak kabul edilmesi ve yetkilerinin daha fazla olması, il özel idarelerinin kaldırılarak bunların yerine, Yatırım İzleme ve Koordinasyon Merkezleri'nin kurulması sonucu Anayasada daha önce hiç yer almayan ve öngörülmeyen yeni bir yönetim modeline gidilmiştir. Sonuç olarak bu yasal düzenleme ile merkezi yönetimin gücünün parçalanarak ve bölgesel merkezi yönetimlerin oluşturulduğunu söyleyebiliriz (Özer, 2013:120-121).

- E-Belediyecilik: E-devlet/e-belediye uygulamaları ile vatandaşlar bir şifre ile devlet/belediye tarafından verilen birçok hizmete dijital ortamda ulaşabilmektedir (Yılmaz, 2019:510). E-devlet uygulamalarının 
belediyelerde etkili kullanımı, birçok hizmete ve güncel bilgilere halkın 24 saat boyunca kolay, ekonomik, etkin ve kesintisiz bir şekilde erişim sağlayabilmesini; talep, şikâyet ve isteklerini hızlıca iletebilmesini sağlamaktadır. Belediye web sayfaları ve mobil uygulamalar üzerinden gerçekleştirilen ebelediyecilik uygulamaları kurumsal açıdan "tanıma" ve "tanıtma" faaliyetlerinin gerçekleştirilmelerini sağlamaktadır (Mecek, 2017:1841). E-belediyecilikle yerel yönetim ve vatandaş arasındaki iletişimin iyi bir noktaya ulaştırılması hedeflenmektedir. E-belediyecilik kapsamında sunulan çeşitli hizmetlere yönelik bilgilere erişen vatandaşlar, belediyenin internet sitesinde bulunan "başkana ulaşın" ve "online anket" gibi bölümler ile halk, belediye yönetimlerine doğrudan görüş ve düşüncelerini iletmekte ve yerel düzeydeki yönetsel süreçlere aktif bir şekilde katılabilmektedir (Güven ve Alan, 2019:56).

- Mobil Belediyecilik (Mobil Belediye): Son yıllarda Mobil devlet uygulamalarının sağladı̆̆ı olanakların farkında olan birçok belediye mobil belediyecilik adı altında her geçen gün yeni bir yerel hizmeti mobil belediyecilik ile hayata geçirmektedir. Mobil uygulamalar, yönetişim yaklaşımı doğrultusunda zaman ve mekândan bağımsız bir şekilde gerçekleştirilmekte ve vatandaşların görüşleri alınarak yönetime katılmaları sağlanmaktadır. Mobil belediyecilik kapsamında yapılan uygulamalarla vatandaşa hizmet sunulan hizmetin kapsamı artmaktadır. Ayrıca, vatandaşların mobil belediyecilik uygulamalarıyla kamu hizmetlerine erişimi kolaylaşmakta, yerel karar ve faaliyetlere halkın doğrudan katılımı ile temsili demokrasiden kaynaklanan sorunları belirli bir ölçüde gidermektedir (Güven ve Alan, 2019:56-57). Mobil belediyecilik (m-belediye), e-belediye uygulamalarının mobil telefonlar üzerinden hayata geçirilmesi olarak da kısaca tanımlanabilmektedir.

\section{3. İNGILTERE'DE YEREL DEMOKRASİ VE KATILIMIN GELIŞMESİ}

İngiltere'de yerel yönetimler; belli bir yerleşim alanı, mahalle ya da bölgeye ilişkin konularda, parlamento tarafından kendilerine verilen görev ve yetkiler doğrultusunda faaliyetlerde bulunan, seçilmiş organlarca yönetilen kuruluşlardır. İngiltere'deki her bir bakanlık kendi hizmet ve faaliyet alanına göre bölgesel ya da alt düzeylerde örgütlenmeler oluşturmuştur (Yamaç, 2014:4). İngiltere'deki idari sistem içinde yerel yönetimlerin temelini 1215 Magna Carta'ya dayandırmak mümkündür. Bu doğrultu da İngiltere'nin en uzun yerel yönetim geleneğine sahip olan bir ülke olduğunu söylemek mümkündür (Koçak, 2008:143).

İngiltere'nin yazılı bir anayasaya sahip olmaması aynı zamanda yönetimlerin de anayasal dayanağa sahip olmamasına yol açmıştır. Buna rağmen, merkezi hükümetin aksine 1960'lı yıllardan itibaren yerel yönetimler yasal mevzuata dayanak varlığını sürdürmektedir (Worthy vd., 2011:12). Yerel yönetimler, yerel halkın ihtiyaç ve beklentilerini karşılamanın önetesinde görev anlayışına sahiptir. Bununla birlikte yerel yönetimlerin, vatandaşa yönelik olan tavrı bireylerin konumu, statüsü ve görevinden bağımsızdır. Öyle ki yerel yönetimler, halkın ihtiyacı olan hizmetleri zamanında ve yerinde karşılamak için çaba harcamaktadır. Yerel yönetimlerin böyle bir anlayışa sahip olması paha biçilmez bir önem taşımaktadır (Friends of The Earth, 2008). Çalışmanın bu bölümünde öncelikle yerel yönetimlerin tarihsel süreçte yerel yönetimler ve yerel demokrasi incelenecektir. Sonrasında İngiltere'deki başlıca yerel yönetim birimlerine değinilecek ve son olarak yerel yönetimlerdeki katılım mekanizmalarına yer verilecektir.

\subsection{Tarihsel Süreçte Yerel Yönetimler ve Yerel Demokrasi}

Çalışmanın bu kısmında İngiltere'de yerel yönetimler ve yerel demokrasi tarihsel sınıflandırma yapılarak incelenmiş̧ir. Bu kapsamda öncelikle sanayi öncesi yerel yönetimler, 1832-1974 dönemi, 1974 sonrası dönem şeklinde üç ana sınıfa ayrılarak değerlendirilmiştir.

\subsubsection{Sanayi Devrimi Öncesi Yerel Yönetimler}

İngiltere'de yerel hizmetlerin karşılanması için bölgesel düzeyde belli alanlarda uzmanlaşan ve özel amaçlı birçok yönetim birimi bulunmaktadır. Yerel yönetimlere belli görevler yükleyen ilk yasa Kraliçe I. Elizabeth tarafindan 1601 yılında yapılmış ve yoksullukla mücadele başta olmak üzere yerel yönetimleri görevlendiren birçok madde bulunmaktaydı.18. yüzyılda hızlı bir endüstrileşme dönemine girilmesiyle birlikte kentleşme ve nüfus artış hızının yüksek olması ekonomik ve sosyal yapıda da köklü değişimlerin ortaya çıkmasına yol açmıştır. Bu sorunların çözümünde yerel yönetimler daha fazla görev ve sorumluluk almaya başlamıştır. Konut, sağlık, düşkünevleri, eğitim, ekonomi, çevre sorunları vb. alanlarda temel alanlarda önemli görevler üstlenmiş̧lerdir. Bu kadar sorumluluk ve göreve rağmen yerel yönetimler, merkezi yönetim tarafından yönetsel, 
mahkemeler tarafında da adli denetime tabiidir. Dolayısıyla yerel yönetimlerin özerkliği yalnızca kendilerine yüklenen görev ve sorumluluk alanları doğrultusunda kural koyma ve iş yapma ile sınırlı tutulmuştur (Yamaç, 2014:1).

İngiltere'de 1830'lu y1llara kadar yerel yönetimler, dünyanın birçok ülkesi tarafından örnek alınan evrim sürecine girmiştir. 1606 y1lında gerçekleşen Norman işgali öncesi Anglo Sakson dönemdeki kasabalar ve küçük mezralara kadar olan her alanda toplumsal ve yerel ihtiyaçların karşılanması amacıyla günümüzdeki yerel yönetimlerin temelini oluşturulan parish counciller kurulmuştur. 1606'tan bu yana yerel yönetimler merkezi hükümet ve parlamento arasındaki ilişki dikkate alındığında iki temel ilkeye dayandığı görülmektedir (Erdemir, 2010:25). İngiltere'de merkezi hükümet tarih boyunca hiçbir zaman yerel yönetimlerin yetkilerini kısıtlayan ve ona bir alternatif olarak sunulabilecek teşkilat oluşturmamıştır ve parlamento da yerel yönetimlerin görev, sorumluluk ve hizmetlerini kısıtlayacak şekilde hiçbir düzenleme yapmamıştır (Keating, 1993:3).

10-15. yy arasında İngiltere'de dünyadaki diğer Batılı Avrupa ülkelere göre daha fazla gelişmiş bir yerel yönetim geleneği ve sistemine sahipti. Adalet, güvenlik, seçim, yoksulluk, arazilerin idaresi, sağlik, vb. birçok konuda yerel yönetimler görev ve yetkilerini 19. yüzyıl ortalarına kadar elinde tutmuştur (Wollmann, 2000:34). Fakat sanayi devrimi sonrasında bu sistem maalesef ihtiyaçların karşılanmasında yetersiz kalmıştır. Ekonomik, sosyo-kültürel, siyasi, sağlık, çevre ve kentsel vb. alanlarda sorunların artması ile birlikte bu sorunların çözümü için merkezi yönetim birtakım adımlar atmak zorunda kalmış, bu kapsamda da çağdaş yerel yönetim sisteminin temellini atan düzenlemeler yapmıştır (Özkan, 2015:51).

\subsubsection{2-1974 Dönemi Yerel Yönetimler}

İngiltere'de yerel yönetim önemli dönüm noktalarından birisi 19. yüzyıl olmuştur. 19. yüzyılın sonlarına doğru endüstrileşmenin hızlanması yerel yönetim sisteminde de önemli değişimlerin yaşanmasına yol açmıştır. Yerel yönetimlere yönelik en geniş yasal düzenlemeler ise 1832 tarihli “The Great Reform Act” de yapılmıştır. Çağdaş yerel yönetim sisteminin temeli ise 1834 tarihli "The Poor Law Amendment Act”"e dayanmaktadır. (Özkan, 2015:52). Yerel halkın oy hakkı genişletilmiş, toprak sahipleri ile birlikte erkeklere de oy hakkı tanınmıştır. 1835 yılında düzenlenen "Municipal Corportion Act" ile denilen yerel councillerin temelleri atılmıştır (Chandler, 2001:18).

1832 ve 1834 y1lında gerçekleştirilen bu kanuni düzenlemelere rağmen ülkedeki ilk genel yasal düzenleme 1835 yılında Municipal Corporation Act ile yapılarak, yerel birimlerin görev ve sorumluluk alanları, karar organlarının sahip olduğu yetkiler belirlenmiştir. Ayrıca yerel yönetimlerin görevlerini ve hizmetlerini sunabilmesi için vergi koyma yetkisi kabul edilmiştir (Usta vd., 2017:71).

1888 yılında kabul edilen Local Government Act ile ilk kez County Affairs (Yerel Yönetim Birimleri Işsleri Görevleri), yerel yönetimlerin görev ve işlerini yerine getirme yol ve yöntemlerini içeren prensipler kabul edilmiştir. Bu düzenleme ile birlikte yerel yönetimlerin varlı̆̆ı parlamento tarafinda da kabul edilmiştir. Böylece yerel yönetimler yasal bir dayanağa kavuşmuştur. Bu kanunun en önemli özelliklerinden birisi de yerel yönetimlerin ilk kez yasal olarak ele alınmasına olanak tanımasıdır (Öcal, 2001:5).

1920’li yıllara kadar olan dönem İngiltere'de yerel yönetimlerin altın çağı olarak kabul edilmektedir. Ancak bu tarihten sonra refah devleti anlayışının ortaya çıkması sonucu merkezi yönetim daha önce yerel yönetimler tarafından yerine getirilen bazı hizmetleri kendi sorumluluğu altında yürütülmesine yönelik müdahalelerde bulunmuştur. İkinci Dünya Savaşı sonrasında merkezi yönetimin birtakım görevleri "Welfare State" altında toplamıştır. Böyle bir değişimin sonrasında ise yerel yönetimler artık merkezi hükümet tarafindan verilen mahalli düzeyde bazı hizmetleri yerine getiren "agent" (merkezi hükümet temsilcisi ya da alt kuruluş birimi) konumuna gelmiştir. 1945'ten itibaren İşçi Partisi'nin iktidara gelmesi yerel yönetimler için yeni bir dönemin başlangıcı olmuştur. Bu dönemler, özellikle yerel yönetimler için yetki ve fonksiyon kaybının zirvede olduğu dönemler olmuştur. Çünkü İşçi Parti bazı hizmetlerin küçük birimler yerine büyük birimler tarafından daha etkin bir şekilde yerine getirilebileceğini savunuyordu (Özkan, 2015:52).

\subsubsection{4 ve Sonrası Yerel Yönetimler}

Günümüzde yerel yönetim sisteminin mevcut yapısını büyük oranda belirleyen 1972 yılında kabul edilerek 1974 y1lında yürürlüğe giren Yerel Yönetimler Yasası "The Local Government Act” ile atılmıştır. Bu kanun, 1986 yılında yeniden düzenlenerek günümüze kadar varlığını korumuştur. İlgili düzenleme ile İngiltere'deki yerel yönetim birimlerinin sayısının azaltılması ve günümüzde mevcut olan üç sınıflı bir yerel yönetim sisteminin 
oluşturulması yasal güvence altına alınmıştır. Bu sınıflandırma kapsamında ilk basamakta il, ikinci basamakta bölge ve üçüncü basamakta da köy yer almaktadır. Bununla birlikte bu birimler metropoliten olup olmamalarına göre de ayrı bir sınıflandırmaya tabi tutulmuştur. Büyük Londra Yönetimi ise ayrı bir yasal düzenleme ile oluşturulmuştur. Dünyada kamu yönetimi reformlarının en sık gerçekleştiği ülkelerden biri İngiltere'dir. Özellikle yeni kurulan, birleştirilen, kaldırılan, niteliği değişen yönetsel birimlere bu ülkede daha fazla rastlanmaktadır. İngiltere'de ki en kapsamlı reform hareketi 1980'li yılların başından itibaren Thatcher hükümeti ile başlamıştır. Bu dönemde yapılan reformlar ekonomik, siyasi, yönetsel, sağlı, askeri, eğitim, vb. birçok alanı etkilemiştir (Arslan, 2018:2872).

Margaret Thatcher'in 1980'lerden itibaren iktidara gelmesi reform rüzgârlarını daha da güçlendirmiştir. Thatcher, ilk on yıllık sürede özel sektör yönetim anlayışının kamuya yansıtılmasını; kamuda rekabetçi, müşteri odaklı, etkin bir yönetim anlayışının oluşturulmasına yönelik çaba harcamışır. 1979-1990 yıları arasında iktidarı elinde tutan Thatcher, muhafazakâr parti, o dönemlerde tüm dünyada hâkim bir eğilim haline gelen neoliberal yönetim anlayışı ve yeni kamu yönetimi anlayışını temel alındığı âdem-i merkeziyetçi politikalar oluşturmuştur. Ancak bu dönemde yerel birimlerin yetki ve görev alanlarında daralmaya gidilmiştir. İlgili dönemde yapılan reformlar yalnızca merkezi hükümete değil, aynı zamanda yerel yönetimlere yönelik olarak da gerçekleştirilmiştir. Bu kapsamda yerel yönetimler ile ilgili köklü reformlar yapılmıştır. Özellikle merkezi yönetim-yerel yönetim arasındaki ilişkileri belirleyen reformlar daha dikkat çekici olmuştur (Usta vd. 2017:72).

Merkezi hükümet, yerel yönetimlerin gelir kaynaklarını kısıtlarken, aynı zamanda yerel yönetimler üzerindeki kontrolünü de artmıştır. Özellikle yerel politikalar hazırlanırken yerel yönetimlere danışılmamış, öneri ve uyarılarına yer verilmemiştir. Bütün bu uygulamalar merkez ve yerel arasındaki ilişkilerin gerginleşmesine ve yerel demokrasi ile özerkliğin zedelenmesine yol açmıştır (Kösecik, 2000:25).

Dünyadaki Avrupa ülkelerinin büyük çoğunluğunda görüldüğü gibi 1980'li yıllar İngiltere için de yerel ve bölgesel dönüşümlerin yaşandığı dönem olmuştur. Bu dönemlerde neoliberal politikaların uygulanması ile Thatcher hükümeti İngiltere'de yerel yönetimleri verimsiz ilan ederek yerel birimlerin yetki ve görevlerinin özelleştirilmesi ve merkezileştirilmesini sağlayan yasal düzenlemeler oluşturulmuştur. Merkezileşme eğilimlerinin giderek artmasıyla yerel yönetimlerin faaliyet alanları da daralmıştır. 1980'lerden sonra ise devlet hizmet sağlayıcı rolü hizmetlerin üretiminden hizmetlerin temel alıcısı haline gelmiştir. Devlet finansman konusundaki bazı yetkilerini ise doğrudan kullanıcılara bırakmıştır (Yamaç, 2014:4).

Köklü değişimler sonucunda yerel yönetimlerin etkinlikleri önemli ölçüde azalmış, artık hizmet sunucu olmaktan çıııp doğrudan hizmet düzenleyicisi konumuna düşmüşlerdir. Daha önce yerel yönetimler tarafından sunulan çoğu hizmet artık özel sektör tarafından sunulması yerel yönetimlerin halkın gözünde itibar kaybetmesine yol açmıştır. Bu durum, yerel seçimlere katılım oranını azaltmıştır. Örneğin "Sheffield City Council" seçimlerinde katılım oranı en son seçimde \%28 olarak gerçekleşmiştir. Aynı zamanda yerel halkın büyük bir çoğunluğu meclis üyelerinin ve belediye başkanının kim olduğunu dahi bilmemektedir (Erdemir, 2010:27).

1985 yılında yerel yönetimlerin tekrar ele alınması ile Thatcherizm rüzgârının etkisiyle yeniden yapılandırılmıştır. Yapılan bu reformlarla Londra Büyükşehir Belediyesi ortadan kaldırılmış, yerel yönetim birimlerinin sayısı attırılmış, görev ve sorumlulukları artık özel amaçlı kamu kurumları ve yarı özerk örgütler arasında dağıtılmıştır (Parlak ve Ökmen, 2015:92). Böylece 1990’lı y1llara kadar yerel yönetimlerin görev alanı daraltmıştır. Bu kapsamda da yerel birimlerin görev ve sorumlulukları bölgesel ve yerel düzeyde örgütlenen yarı resmi toplum kuruluşları ve hükümetten bağımsız olarak tanımlanan Quango ve ajanslar ile paylaştırılmıştır. Ayrıca sivil toplum kuruluşları, hükümetten bağımsız olarak, merkez-yerel arasındaki işbirliğinin sağlanmasındaki etkinlikleri ile önem taşımaktadır (Yamaç, 2014:5).

1990'lı yıllardan beri İngiltere'de tüm dünyada hâkim bir eğilim haline gelen yerel yönetişim uygulamaları hizmetlerin hem daha hızlı ve etkin, hem de verimli sunulmasını amaçlayan en önemli yaklaşımlardan biri haline gelmiştir. Yerel yönetişim ile kamusal örgütlerin şeffaflaştırılması, halkın yönetime ve karar sürecine katılımını arttırması ve sivil toplumların yönetimde söz sahibi olmalarını sağlamak hedeflenmiştir. Ancak merkezi yönetimin yerel yönetimler üzerindeki sıkı denetimi ve ekonomik, sosyo-kültürel, eğitim, vb. alanlardaki bazı hizmetleri doğrudan yürütme arzusu gelişmelerin önünde zaman zaman engel olmuştur (Parlak ve Ökmen, 2015:91).

1998 yılında halk oylamasının yapılması ile Londra Büyükşehir Belediyesi’nin yeniden kurulmasına karar verilmiştir. 1999 yılında kabul edilen Büyük Londra Otorite Yasası, 2000 yılında belediye başkanının doğrudan ilk kez halk tarafından seçilmesine ve 25 üyeli bir meclis oluşturulmasına karar verilmesi önemli gelişmeler arasında değerlendirilmektedir (Özkan, 2015:53). 
2000'li yıllarda yerel yönetimlerde halk katılımı ve demokrasinin daha etkin bir hale getirilmesi amaciyla merkezi hükümet Yeni Yerel Yönetimler Yasası çıkartmıştır. Bu yasanın kabul edilmesi ile geleneksel olan "Yönetici - Meclis Modeli", "Lider - Kabine Modeline" farkl1lık katan "Seçilmiş Belediye Başkanı - Kabine Modeli" ve "Seçilmiş Belediye Başkanı - Meclis Modeli" kabul edilmiştir (Cole, 2003:182).

Önceki yasal düzenlemelerden farklı olarak belediye başkanını yerel halk tarafından seçilmesi esasına dayan sistemin uygulanması ile birlikte yerel düzeyde bir liderlik anlayışııın oluşturulması hedeflenmiştir. 2011 yılına gelindiğinde ise Yerel Yönetim Yasası'nın çıkarılması ile birlikte yerelleşme söylemlerine daha çok önem verilmiştir (Karasu, 2013:217). Ancak 2011 yılında çıkarılan bu yasada merkezi yönetim, yerel yönetim birimlerinin örgütlenme ve işleyişine müdahale imkânı sağlayan birçok yetkiye de yer vermiştir. Kısacası son düzenlemelerle merkez yönetim - yerel yönetim arasındaki ilişkiler özünde diğer düzenlemelerden çok farklılık arz etmemiştir. 2011 yılında kabul edilen yeni yasada bakanlara tanınan yetkilerin öncekilere göre çok daha fazladır. Bu doğrultuda bu yeni yasanın retoriği yerelleşmeci olmasına rağmen özünün ise merkeziyetçi olduğunu söylemek mümkündür (Usta vd. 2017:73).

\subsubsection{Yerel Yönetimlerde Katılım Mekanizmaları}

İngiltere'de halkın yerel yönetimler düzeyinde yönetime (kararlara) katılma ve yönetim süreçlerini etkileme mekanizmaları bulunmaktadır. Bu araçların bazıları şunlardır;

- Mahalle Büroları: İngiltere'de yerel halkın hangi hizmetleri istediğini ve halkın yönetime katılımını sağlamak amacıyla yerel yönetim birimleri mahalle büroları açmaktadır. Bu bürolar halkın görüş, talep ve önerilerini dinlemektedir. Örneğin Birmingham kentinde belli aralıklarla halka açık olarak yapılan toplantılarda yerel alana yönelik kararlar alınmaktadır. Ancak alınan kararlarda belediye meclisi ve mahalle bürolarının kararlarının çelişmesi halinde, mahalle bürolarında alınan kararlar ekseninde son karar verilmektedir (Özkan, 2015:65).

- Beyaz Kitap: Yerel halkın, idarenin sunacağı hizmetler ve kentsel politikalar konusunda karar alınmadan önce, yapılacak iş ve faaliyetlerle ilgili olarak yapılacak değişimler ve bunların etkileri hakkında yapılan açıklamalar ve önerilerin bulunduğu kitaptır. Beyaz kitapta politika, faaliyet, iş ve eylemlerde halkın görüş ve önerilerine bağlı olarak değişiklikler yapılmaktadır (Yüksel, 2005:287-288).

- Halk Jürisi: İngiltere'de üniversiteler gibi tarafsız olan kurumlar kapsamında sayıs1 12-16 arasında değişen ve halkın her kesiminden kişilerin bulunduğu bir jüri oluşturulmaktadır (www.gov.uk/government). Ancak, bu jürilere seçilen kişiler belirlenen konularda bilgi sahibi olmakla birlikte katılım sağladıkları için belli ücretler elde etmektedir. Belirlenen konular kapsamında yapılan çalışmalar sonucunda jüri bir rapor hazırlamakta ve bu rapor meclise sunulmaktadır (Read, 2014:42). Bu katılım mekanizmasının temel amacı etnik azınlıklar, alt gelir grubu ve yoksullar gibi halkın hemen her kesiminden olan insanların fikirlerinin karar alım sürecinde etkili olduğunun ortaya koyulmasıdır. Ancak bu katılım mekanizmasının temel sorunu karar alma sürecinin çok yavaş olmasıdır. Bu yöntem, sürekli uygulanabilme özelliğine sahip olmamakla birlikte genellikle halkın hayatını önemli ölçüde etkileyen konularda kullanılmaktadır (Erdemir, 2010:40-41).

- Halk Panelleri: İngiltere'de halkın katılımının sağlanmasında en fazla kullanılan yöntemlerden biridir. İki farklı şekilde uygulanmaktadır. Birinci olarak, genellikle belli bir alanda oturan kimselerin tamamının temsil edildiğinin varsayıldığı belli sayıda kişi tespit edilir (500 ila 7000 arasında değişsebilmektedir). Bu kişilerin belli konulardaki görüşleri yapılan anketlerle belirlenmekte ve karar alım sürecinde dikkate alınmaktadır (www.bankofengland.co.uk). İkinci olarak ise yerel halkın tamamını temsil ettiği kabul edilen birkaç bin kişi belli bir süreliğine (genellikle bir hafta) belli konu veya sorun hakkında bir şeyler öğrenek kendi fikir ve düşüncelerini koymak amaciyla bir araya getirilmektedir (Brown, 2006:204). Bu süre sonunda grubun kararları dikkate alınarak bir rapor hazırlanmaktadır. Örneğin Norfolk Citizen Paneli, yaklaşık 7000 üyesi olan bir paneldir. Bu panelin üyeleri her iki yılda bir değişmekte ve eni üyelerin seçilmesi bu bölgede oturan 70.0000 kişiye yapılan anket sonucunda bağımsız anket şirketleri tarafından belirlenmektedir. Panel üyesinin seçilmesinde menfaat gruplarının yerine sıradan halkın içinde seçilmesidir (Rippe ve Schaber, 1999:78). Belli konuda anket şirketi tarafından hazırlanan anketler panel üyelerine gönderilir ve yerel hizmetler komsundaki görüş, öneri ve talepleri istenmektedir. Yapılan anket sonuçları değerlendirilip, raporlar hazırlanmakta, yerel yönetimlere sunulmakta ve sonuçlar halka bildirilmektedir (www. norfolkcitizenspanel.org). 
- Halka Açık Toplantılar: İngiltere'de birçok yerel yönetimin kullandığı bu toplantılar, yerel alanda yapılması planlanan değişiklikler konusunda halkı bilgilendirme amacıyla düzenlenmiş (Hambleton ve Sweetıng, 2004:475) olup, tüm halkın katılımına açık olan mekanizmalardır. Ancak bu toplantılara konunun uzmanları, sivil toplum örgütleri ve menfaat grupları katılmakta iken, bireysel katılımlar yetersiz kalmaktadır (www.legislation.gov.uk/). Halka açık toplantı mekanizmasına örnek olarak "Leicestershire County Concil" ve "Leicester City Council" tarafindan katı atık yönetimi ile ilgili yapılması planlanan değişiklikler konusunda halkın bilgi sahibi olmasını sağlamak amacıyla yaptıkları (3 Mart 2009 ile 6 Mart 2009) halka açık toplantılar verilebilir. Uygulamada bu örnekler arttırılabilmektedir. Örneğin "Sheffield City Council" neredeyse her y1l geleneksel şekilde vergi bütçesinin kesinleşmesinden önce halka açık toplantılar yaparak toplantı sonucu elde edinilen sonuç bildirgesini yerel halka duyurarak karar alım sürecinde de dikkate almaktadır (Erdemir, 2010:43).

- Referandum: Yerel halkın belli konularda karara varmasına olanak sağlaması açısından önem taşımaktadır. Ancak katılımın yetersiz olması halinde çoğunluğu temsil etmeyen görüşler ortaya çıkmakta ve kabul edilmektedir (Fishkın ve Jowell, 2000:657). Bununla birlikte maliyeti oldukça yüksek olan bir katılım yöntemi olmakla birlikte genellikle genel ya da yerel seçimlere denk gelmesi sağlanmaktadır. Bu katılım mekanizması İngiltere'de genellikle halkın gündelik hayatını önemli derecede etkileyen kararların alınmasında kullanılmaktadır (www.legislation.gov.uk). Bunun en güzel örneği İngiliz hükümetinin 1997 yılında yerel yönetimlerin modernleştirilmesi amacıyla seçilmiş bölge meclisi ve belediye başkanının uygulanması konusunda alınacak olan kararın referandum yoluyla uygulanması için kanun çıkarmasıdır (Diamond ve Liddle, 2003:106). Bu kanunun çıkmasından sonra ülke genelinde 37 yerel alanda referandum yapılmıştır. Hem İngiliz hükümeti hem de yerel yönetimler genellikle halkın benimsemesini istediği önemli değişikleri referanduma başvurarak açıklamaktadır (Erdemir, 2010:43-44).

- Anket: İngiltere'de belirli politik ve siyasi konularda yerel halkın nabzını ölçmek amacıyla kullanılan bir katılım mekanizmasıdır. Genellikle halkı temsil ettiği düşünülen bir grup seçilmekte ve yerel yönetimlerin yapmayı hedeflediği değişiklikler konusunda bu grubun görüşlerine başvurulmaktadır. Anket telefon, posta, internet ve yüz yüze görüşme gibi çeşitli yollarla yapılabilmektedir. İngiltere'de yerel yönetim birimlerin sundukları hizmetler konusunda yerel halkın düşüncesini, önerisini, eleştirisini, memnuniyetini, vb. durumları öğrenmek amacıyla anketi kullanmaktadır. Örneğin son zamanlarda "Birmingham City Council" kentsel ve çevre sorunları konusunda halkın şikâyet, talep, beklenti ve önerilerini öğrenmek amacıyla anketler yapmaktadır(www.local.gov.uk).

- Odak Grupları (Focus Group): Halkın fikir ve düşüncelerinin ölçülmesinde ne sık kullanılan yöntemlerden biridir. Bu gruplar genellikle halkı temsil ettiği düşünülen 6-12 arasında bireylerden oluşmaktadır. Grup üyeleri belli gün ve saatlerde toplanarak belirlenen konulardaki düşüncelerini açık bir şekilde ifade etmekte, günler ve saatler sonrasında raporlar hazırlanmaktadır (www.newlocal.org.uk). Bu katılım mekanizmasına verilebilecek en iyi örnek Sheffield City Council Abbeydale Grange adlı ortaokulda eğitim ve öğretim iyileştirilmesi amacıyla yapılması planlanan değişikliklerle ilgili öğrenci velilerinden bir grup oluşturulması ve onların görüşlerine başvurulmasıdır. Görüşmeler sonucu hazırlanan rapor "City Council”"e sunularak alınan kararlarda görüşler dikkate alınmıştır (www.sheffield.gov.uk).

1999 yılında çıkarılan Londra Büyükşehir Yasası, belediye başkanı, belediyenin stratejilerini belirlemiştir. Bununla birlikte bu yasa ile Londra Büyükşsehir Belediye Meclisi ve meclis bünyesindeki alt idari birimleri, alt kademe belediye meclislerini kentsel alandaki baskı ve çıkar gruplarının, gönüllü kuruluşların, sivil toplum örgütlerinin, etnik ve dini grupların, iş ve ekonomi çevrelerinin yerel alana yönelik oluşturulacak politikalardaki görüşlerinin alınması zorunluluğu getirilmiştir (Harrison vd., 2004:907). Bu kapsamda büyükşehir belediyelerindeki temel katılım mekanizmaları şunlardır (Canpolat ve Haktankaçmaz, 2010:101-102);

- Soru Saati: Bu katılım mekanizması, yerel halkın Londra Büyükşehir Belediye Başkanı ve belediye bünyesinde yer alan dört idari yetkilinin de dâhil olduğu belediye yetkilerini sorguya çekmesini ifade etmektedir. $\mathrm{Bu}$ soru saatlerinde gündemin belirlenmesi ve toplantının organize edilmesi belediye tarafından yapılmaktadır. Yılda en az iki defa düzenlenen bu toplantılara Londra'nın farklı kesimlerinde bulunan çok sayıda bireyin katılmaktadır.

- Paydaş Toplantıları: Genellikle sayısı 17 olan, katılımcıların yerel politika geliştirme konusunda doğrudan bilgi edinme imkânına kavuştuğu bir katılım mekanizmasıdır. Katılımcıların niteliğine göre bu toplantıların da isimleri değişmektedir. Bu guruplar genellikle emekliler, öğrenciler, sığınmacılar, dini gruplar ve yalnız ebeveynler gibi alt gruplarıdır. 
- Başkanın Politika Komisyonları: Londra Büyükşehir Yönetimi yasasına göre belediye başkanı sağlık, kentleşme, çevre ve sürdürülebilir kalkınma konusunda politika geliştirmekle yükümlüdür. Bu süreçte de yerel halkın doğrudan katılımının sağlanması için bu komisyonlar oluşturulmuştur. Komisyonun üyeleri konunun uzmanları arasından belediye başkanı tarafından seçilmektedir. İlgili taraflar belirlenen konuları görüştükten sonra belediye başkanına görüş ve önerilerini sunmaktadır. Bu komisyonlara örnek olarak Başkan'ın Çevre Komisyonu verilebilir. Bu komisyon belli konularda karar alırken kamu-özel sektör birlikleri ve sivil toplum örgütlerini de kapsayan yaklaşık 40 aşkın kişinin katılımı ile atölye çalışmaları yapmaktadir.

- Tek Adımda Bilgilendirme: İngiltere'de yerel halkın yerel hizmetler konusunda bilgi sahibi olmasını sağlamak için Londra'da halka sunulan yerel hizmetler konusunda vatandaşın bilgi sahibi olmasını tek bir telefon numarasına bağlanarak öğrenmelerine dayanmaktadır. Yerel yönetimlerdeki katılım mekanizmalarını bu şekilde açıkladıktan sonra çalışmanın amacı doğrultusunda Türkiye ve İngiltere'yi yerel demokrasi ve katılım açısından karşılaştırabiliriz.

\section{TÜRKIYE VE INGILTERE'NIN KATILIM VE YEREL DEMOKRASI AÇISINDAN DEĞERLENDIRILMESI}

Çalışmanın bu bölümünde iki ülke arasında yerel demokrasi ve katılımı etkileyen halkın katılımı ve katılım mekanizmaları; yerel yönetimlerin yasal dayanağı, idari vesayet denetimi; yeni kamu yönetimi, yönetişim ve yerelleşme politikaları gibi hususlar üzerinde karşılaştırma yapılmıştır.

\subsection{Halkın Katılımı ve Katılım Mekanizmaları}

Türkiye'de yerel katılıma bakıldığı zaman yalnızca seçimlerde temsilci seçme noktasında işlevsel olduğu görülmektedir. Seçimlerden sonra halkın yerel karar alma sürecinde yeterince aktif rol almadığ görülmektedir. Oysaki yerel meclis toplantılarının halka açık olduğu yasalar düzenlemelerde belirtilmiş ve herkesin istediği zaman bu toplantılara katılabileceği belirtilmiştir. Fakat halkın bu toplantılara katılım konusunda çok istekli olduğunu söylemek mümkün değildir. Halkın büyük bir kısmı, yerel ve siyasal katılmayı yalnızca seçimlere katılma ve bazı isteklerini belirli araç ve mekanizmalarla ilgili makamlara iletmeden ibaret görmektedir. Böylece yerel konu ve sorunlara yönelik halkın karar alma sürecindeki müdahalesi çok sınırlı olmaktadır. Bu sınırlı katılımın temel nedeni ise halkın bu süreçte hiçbir etki gücüne sahip olduğuna yönelik inancının bulunmamasıdır. Özellikle belediye yasasında belirtilen hemşehri katılımı ve denetiminin yok denecek kadar düşük düzeyde olması hem kurumsal hem de uygulamada bazı yetersizliklerin olduğunu göstermektedir.

Türkiye'de katılıma olan ilginin az olmasının temel nedenlerinden biri de anayasal ve yasal olanakların sinırlı olmasıdır. Karar alma süreçlerinde sivil toplumun sürekli dışlanması ve bireyin siyasal katılımı endişe ile karşılaması, Türkiye'nin önemli sorunlarındandır (Çukurçayır, 2012:187). Türkiye'den farklı olarak İngiltere'deki sivil toplum anlayışı; kentsel, sosyal, çevresel ihtiyaçların karşılanması, bireylerin kendiler tarafından belirlenen yaşam biçimine yönelik ihtiyaçların karşılanması, eşit, özgür, dayanışmacı ve girişimci bir toplumun oluşturulması için vazgeçilmez mekanizmalardan biri olarak kabul edilmektedir. Böyle bir yaklaşım ile İngiltere'de merkezi yönetim, yerel yönetimleri ve yerel yönetimlerle sık1 bir işbirliği içinde olan sivil toplumu farklılıkları bünyesinde barındıran bir değer olarak kabul etmektedir. Ülkede sivil toplum, toplumdaki temsil edilemeyen sesini duyurmanın bir aracıdır. Ülkede yapılması planlanan ekonomik, sosyo-kültürel, siyasi, vb. alandaki çok boyutlu değişimlerde halkın isteğinin temsil edilmesinde önem taşımaktadır (HM Treasury Cabinet Office, 2008).

Türkiye'nin katılım mekanizmalarının çok çeşitli olmayışının aksine İngiltere'de yerel halkın yönetimde söz sahibi olması adına birçok kavram oluşturulmuştur. Halkın yönetime katılımı açısından Türkiye'de yerel halkında görüşlerinin alınmasının da istenilen düzeyde olduğu söylenemez. İngiltere'de yerel halkın yönetime katılmasını sağlamak amacıyla halk jürileri, halka panelleri, halka açık toplantılar, herkese açık davetler ve anketler çalışmaları yapılmaktadır. Bu çalışmalar sonucu alınan kararlar yerel yönetimler için genellikle bağlayıcı nitelik taşımaktadır. Yani halkın talep ve beklentileri yerel birimler için önem arz etmektedir. $\mathrm{Bu}$ durum ise halkın kararların alım sürecinde aktif olmasını sağlamaktadır. Ancak Türkiye'de ise halkın yerel yönetim birimlerine doğrudan katılımını teşvik edecek olan Yerel Gündem 21 ve kent konseyleri gibi katılım mekanizmalar İngiltere'ye kıyasla yetersiz kalmaktadır. Türkiye'de 5393 sayılı Belediye Kanun'unda yer alan kent konseyi doğrudan bir katılım mekanizması olarak kabul edilmesine rağmen kent konseyi tarafından alınan kararların belediye meclisinin ilk toplantısında görüşülmesinde ciddi sorunlar yaşanmaktadır. $\mathrm{Bu}$ durumun 
temel nedenleri arasında kent konseylerinin halk tarafından yeterince tanınmaması, belediyenin bir birimi olarak değerlendirilmesi, mali özerkliğinin olmaması, kent konseyleri tarafından alınan kararların belediye tarafindan göz ardı edilmesi ve kent konseyleri tarafından alınan kararların bağlayıcı nitelik taşımaması sayılmaktadır.

İngiltere'de yerel yönetimlerin büyük çoğunluğu, yerel ve kentsel alana yapılması düşünülen faaliyetlerde toplumsal birlikteliğin ve yerel halkın katılımının sağlanmasına oldukça önem vermektedir (Pearce ve Ellwood, 2002:75). Bu kapsamda da yerel halkın taleplerini önemsiz, gereksiz olarak görmemektedir. Yerel yönetim birimleri, yerel halkın (toplumun) gelişmesine yönelik faaliyetlerde ve toplumsal sorunların çözümde halkın katılımın sağlanarak fikrine başvurulmasının önem taşıdığını düşünmektedir. Çünkü halka danışılarak yerel alana yönelik politikalar daha isabetli; sorunlara yönelik çözümler ise daha kalıcı olmaktadır. Yerel alana yönelik faaliyetlerdeki önceliğin belirlenmesinde de yine halka başvurmanın önem taşıdı̆̆ yerel yönetimler tarafindan kabul edilmektedir. Böylece yerel halk, yaşadığı alanda yalnızca bir topluluk olarak değildir. Yerel halk, kentsel alana yönelik politikalarda kararların alınmasındaki başat aktörlerden biridir ve faaliyet ile işgücüne yönelik planlamalarda ortaktır (Improvement And Development Agency, 2008).

İngiltere'de halkın katılıma önem vermesinin en önemli nedeni yerel yönetimlerin gelirlerinin yaklaşık \%40'nı o bölgede toplanan vergiler oluşturmaktadır (Zimmerman, 1999:45). Halk böyle büyük ölçüde maddi destek sağladığından dolayı alınan kararların ortak çıkarlara uygun alınıp alınmadığının hesabını daha aktif bir şekilde yerel yönetimlerden sormaktadır. Türkiye'de özellikle küçük belediyeler ve köylerde vatandaşlar aldıkları hizmetlerin parasını bile tam manası ile ödemediği ve gelirlerin önemli bir bölümü merkezi idareden aktarıldığı için halkta bir hesap sorma bilinci oluşmamıştır (Erdemir, 2010:79).

İngiltere'de yerel seçimlere katılım, Hollanda, Danimarka, İsviçre ve Fransa gibi Avrupa Birliği ülkeleri ile kıyaslandığı zaman, oldukça azdır. Mesela Fransa'daki yerel seçimlere katılım oranı \%25 civarında İngiltere katılım oranından fazladır (Frandsen, 2002:859-860). Hatta İngiltere'de bazı şehirlerde katılım \%30'ların bile altında kalmaktadır. Örneğin Sheffield'da katılım oranı 2003 seçimlerinde \%28 oranında gerçekleşmiştir. Katılım oranlarının oldukça düşük olması hükümeti ve parlamentoyu bu noktada tedbirler almaya zorlamaktadır (Erdemir, 2010:39). Halkın seçimlere katılım oranının düşük olmasının ardında yönetimi ve karar alma sürecini etkileyebileceklerini diğer mekanizmaların olması gelmektedir. Yani halk sadece seçimlere katılarak yönetimi etkilemeye çalışmamakta, katılım mekanizmaları daha fazla önem arz etmektedir (Godfrey, 2007:112).

Hükümet tarafından yapılan ve tartışmaya açılan araştırmada seçimlerde katılımı arttırmak için şunlar önerilmektedir; Seçmenleri oy kullanmaları yönünde zorlamak yerine seçimlerinin tanıtımının yapılması, isimlerinin seçmen listesinde görülmesini istemeyen seçmenler için gizli kayıt sisteminin geliştirilmesi, seçim sandıklarının halkın yoğun olarak bulunduğu iş yerlerine, süpermarketlere, okul ve kolejlere kurulması, oy kullanma süresinin bir günün belli bir dilimi ile sınırlı tutulmaması ve iki veya üç güne çıkarılması, elektronik oylama sistemine geçilmesidir(Erdemir, 2010:39).

İngiltere'de birçok yerel yönetim birimi, katılım ve toplumsal birlikteliğin işbirliği ekseninde yapılmasına oldukça önem vermektedir. Toplumun gelişmesi açısından öncelikli faaliyetlerin yine toplum tarafından en iyi şekilde tespit edileceğini kabul etmektedir. Böylece yerel halk, yalnızca bir topluluk değil aynı zamanda karar veren, işgücü ve faaliyet planlaması yapan yerel bir ortak konumundadır. Başka bir ifade ile yerel halk, sadece hizmet alıcı değildir. Bu doğrultuda yerel yönetimler ve sivil toplum kuruluşları işbirliği ile sosyal sermaye inşa edilmektedir. Toplumsal organizasyonlara ya da yerel birliklere katılım, yerel yönetimler ve halk arasında karşılıklı güven duygusunun oluştuğunu göstermektedir. Böylece herhangi bir yasal zorunluluk olmaksızın halkın kentte karşı taşıdığı ait olma duygusu gönüllülüğe dayalı faaliyetler içinde yer almasını sağlamaktadır. İngiltere'de yerel halk, yalnızca temsili demokrasi ile yetinmemektedir. Bir birey olarak vatandaşlar, mekânsal olarak yerel yönetimlere ulaşmanın daha kolay olduğunun farkında ve bilincinde olarak taleplerini ve isteklerini katılım mekanizmaları ile belirtmektedir. Böylece sadece yönetici eksenli bir yönetim tarzı yerine "yönetişim" eksenli bir yönetim anlayışının hâkim olduğu görülmektedir (Okutan, 2008:91-105).

$\mathrm{Bu}$ çerçevede merkezi ve yerel yönetimlere göre sivil toplum kuruluşları, sosyal sermaye inşa etmektedirler. İngiltere'de yapılan araştırma sonucuna göre; toplumsal organizasyonlara katılımın, insanlar arasında gelişen karşılıklı güven duygusunun oluşumunda çok büyük paya sahip olduğu görülmüştür. Diğer bir ifade ile araştırmanın altını çizdiği nokta; gönüllülüğe dayalı faaliyetler ile ait olma duygusu arasında doğrudan bir bağlantı kurulduğu, bunun da toplumda bulunan diğer insanlara olan güvenin artması ile sonuçlandığıdır. Ayrıca STK'lar kişisel gelişimin ve kendine güvenin sağlanmasına yardımcı olabilmekte ve özellikle de yaşadığı yerle ilgili yapılan faaliyetlere katılım göstermeyen, geniş kitleler arasında kendisini herhangi bir şekilde ifade etme olanağı bulamayan kişiler için firsatlar sunmaktadırlar. 
ÖZER, Mehmet Akif ve KARTAL, Meryem - Yerel Demokrasi ve Katılım: Türkiye ve İngiltere Üzerinden Bir İnceleme

Türkiye'de ise 2019 y1lında yapılan son yerel seçimlere katılım oranı \%84'dür (www.aa.com.tr). Bu rakam İngiltere ile kıyaslandığında oldukça yüksek görünmektedir. Ancak katılım oranı yerel demokrasi konusunda bizi yanıltmamalıdır. Türkiye'de İngiltere'nin aksine halk yönetimi etkilemenin en iyi yolunu seçimlere katılmak olarak görmekte, katılım mekanizmalarına çok fazla önem vermemektedir. Bu durum ise bize Türkiye'de siyasi kültürün tam anlamıyla yerleşmediğini göstermektedir. Sadece ülkede katılım mekanizmalarının olması yerel demokrasinin yerleşmesi için yeterli değildir.

\subsection{Yerel Yönetimlerin Yasal Dayanağı}

Türkiye ile İngiltere yerel yönetim yapısındaki temel farklardan biri Türkiye'de yerel yönetim birimleri anayasal güvence altındadır. 1982 Anayasa'sı önceki anayasalardan farklı olarak yerel yönetim birimlerini detaylıca değerlendirip hukuki bir zemine oturtmuştur. Bu yerel yönetim birimlerinin seçilmiş organlarının da sıfatlarını kaybetmeleri merkezi otoritenin isteği üzerine değil, ancak yarg1 yolu ile gerçekleşmektedir (Uysal, 1984:15).

1982 Anayasası'nın yanı sıra yerel yönetim birimlerinin görev, yetki ve sorumluluklarını daha detaylı bir şekilde açıklayan 5393 sayılı Belediye Kanunu, 5216 sayılı Büyükşsehir Belediyesi Kanunu, 5302 sayılı İl Özel İdaresi Kanunu ve 442 sayılı Köy Kanunu bulunmaktadır. Bu kanunlar ile yerel yönetim organları hizmet sunumunda aktif bir şekilde rol alabilecek düzeye ulaştırılmaya çalışılmıştır. İngiltere'de ise yazılı bir anayasa bulunmamasından ötürü yerel yönetim birimleri her hangi bir anayasal statüye sahip değildirler. Parlamento yerel yönetimler üzerinde her türlü düzenlemeyi yapabilir ve uygulamaya koyabilir. Ancak yasal statüye sahip olmamaları yerel yönetimlere gerekli değerin verilmediği anlamına gelmez. İngiltere'de geçmiş yıllardan bugüne yerel yönetimler ülke için değerli kurumlar olarak görülmüş ve merkezi idare yerel idareler ile görev, yetki ve sorumluluk paylaşımına gitmiştir (Zimmerman, 1999:45).

Üstlendiği hizmetler bakımından İngiltere'de yerel yönetimler, Türkiye'den farklı olarak eğitim ve iç güvenlik hizmetlerini ile de görevlendirilmiştir (Özel ve Eren, 2012:1383). İngiltere'de yerel yönetimler konut, sağlık, eğitim, vb. alanda Türkiye'ye göre daha fazla sorumluluk üstlenmiştir. Bu durum temel gereksinimler karşılanmasında ana hizmet sunan birim olması sebebiyle halkın talep ve beklentilerini daha fazla dikkate almasını, beklentiler doğrultusunda hareket etmesini sağlamıştır. Talepleri karşılanan halkın yerel yönetimlerin faaliyet ve uygulamalarına katılım oranını arttırmaktadır. Bu açıdan İngiltere dünya genelinde yerel yönetim birimlerine gerekli değeri veren sayılı ülkelerden biri konumundadır.

\section{3. İdari Vesayet Denetimi}

Yerel yönetim birimlerinin demokratik birer yapıya sahip olabilmeleri için yaptıkları her eylemde merkezi idarenin baskı unsuru olarak karşılarında olmaması gerekir. Merkezi idarenin uygulamış olduğu vesayet denetiminin aksine, bağımsız ve daha etkin bir denetim sistemi oluşturulmalıdır. Ancak her iki ülkede de yerel yönetimler uyguladıkları tüm faaliyetler merkezi idarenin denetimi altındadır.

İngiltere'de merkezi yönetimler, yerel yönetimler üzerinde yönetsel denetim; mahkemeler ise adli denetim yapma hakkına sahiptir. Bu doğrultuda yerel yönetimlerin özerkliği yalnızca kendileri için ayrılan alanda bazı kurallar koyma ve iş yapabilme olanakları ile sınırlandırılan bir özerklik olmaktadır (Wollmann, 2008:278).

Türkiye'de ise merkezi yönetim anayasaya dayanarak yerel yönetimlerin karar, eylem ve işlemlerinde kamu yararının sağlanması, yerel halkın ihtiyaçlarının gereğince karşılanması, vb. nedenlerden dolayı vesayet denetiminde bulunmaktadır. Fakat anayasa tarafından vesayet denetimine yönelik sınırların çizilmesine rağmen zaman zaman merkezi yönetim denetimin amacı dışına çıkmaktadır. Böyle bir durumda ise merkezi yönetim yerel yönetimler üzerinde kısıtlama, her türlü denetim yapma ve karar alırken yerel birimlerin onayına başvurmadan hareket edebilmektedir. İlgili durum yerel yönetimlerin asıl varlık amaçları ile çelişmektedir. Çünkü yerel yönetimlerin asıl varlık nedeni yerel düzeydeki ihtiyaçların kaynakların etkin ve verimli kullanılarak karşılanmasıdır. Yoğun bir şekilde uygulanan vesayet denetimi yerel yönetimlerin bu amacını gerçekleştirmesinin önünde zaman zaman engel teşkil etmekte, yerel yönetimlerin merkezin bir uzantısı olmasına yol açmaktadır. Bu durum ise modern demokrasi anlayışı ile çelişmekte ve özerkliği olumsuz etkilemektedir.

Türkiye'de geleneksel yerel yönetim kurumlarından yerel demokratik birimlerine geçişteki en büyük engellerden biri bürokratik mekanizmaların direnç göstermesidir. Yönetsel birimlerin (bürokratların) tepki gösterdiği konuların başında kaynakların bölünmesi ve dağıtılmasıdır. Mevcut kaynaklarının ve yetkilerin merkezi yönetim ve yerel yönetimler arasındaki paylaşımı konusundaki sınırlılıklar demokratik yerel yönetim 
anlayışının gelişmesini olumsuz etkilemektedir. $\mathrm{Bu}$ durum ise yerel yönetimlerin gelişmesi ve güçlenmesi yerine daha da güç kaybetmesine, yerel alana yönelik politikalarda arka planda kalmalarına yol açmaktadır. Böylece yerel halkın talep ve beklentilerini en iyi karşılaması ve sorunlara en uygun çözümler getiren yerel yönetim anlayışı gelişmemektedir. İngiltere'de ise yerel yönetim birimleri Türkiye'den farklı olarak yerel hükümet (local government) şeklinde tanımlanmaktadır (Heper, 1986:75).

Türkiye'den farklı olarak İngiltere'de merkezi yönetimin taşra teşkilatı bulunmamaktadır. Dolayısıyla Türkiye'de taşrada merkezi yönetimin valilikler ve kaymakamlıklar tarafindan yürütülen eğitim, sağlık ve konut gibi birçok hizmet yerel yönetimler tarafından veya onların katkısıyla yerine getirilmektedir. Bu noktada, Türk yerel yönetim kuruluşlarına nazaran daha geniş yetki, daha fazla gelir ve özerkliğe sahiptirler. Bu durum ise yerel demokrasi anlayışının gelişmesindeki temel etkenlerden biri olmaktadır.

\subsection{Yeni Kamu Yönetimi, Yönetişim ve Yerelleşme Politikalarına Etkisi}

Merkeziyetçilik anlayışının egemen olduğu Türkiye ve İngiltere'de son yıllarda Yeni Kamu Yönetimi (YKY) ve yönetişim anlayışının da etkisiyle yerel yönetimlerde yetki devrine gidilerek yerelleşme çabalarının verildiği görülmektedir. Bu kapsamda da İngiltere'de yerel yönetimler için yapılan reform çalışmalarının 1980 sonrasında yoğunlaştı̆̆ görülmektedir. Merkezin yaptığı bu reformlar genellikle yerel yönetimler tarafindan sunulan hizmetlerin kapsam ve alanlarının belirlenmesine, mali yapılarının düzenlenmesine yönelik olmuştur. Türkiye'de ise 2003 yılından sonra yerelleşme politikaları kapsamında reformların yapıldığı ve yerel yönetimler için birtakım yasal mevzuatların oluşturulduğu görülmektedir. Bu doğrultuda da tarihsel olarak iki ülke arasındaki reformlar kapsamında yerleştirilmeye çalışılan politikaların benimsenmesi ve uygulanmasında da farklılıklar yaratmıştır. Dolayısıyla yerel demokrasinin ve katılımın tolumda yerleşmesine yönelik uygulamalar Türkiye'de daha geç başlamıştır.

Güçlü bir yerel yönetim geleneğine sahip olan İngiltere'de YKY'nin etkisiyle toplumsal gelişme ve hizmet kalitelerinde gelişmeyi beraberinde getirmiştir. Böylece yerel yönetimlerce sunulan hizmet kalitelerinde yeni standartlar ve öncelikler ortaya çıkmıştır. Yerel halk artık temsili demokrasi uygulamaları ile yetinememektedir. Vatandaş bir birey olarak yerel yönetimlerin halka olan toplumsal ve coğrafi yakınlığın farkına varmıştır. Bu farkındalık ile yerel yönetimlerden olan talep ve beklentilerini katılımcı mekanizmalar aracıllğı ile iletme yoluna gitmiş̧ir. Yani artık yerel halk da yerel yönetim anlayışına karşı yerel yönetişim anlayışının bir parçası olmaktadır. Kısacası yerel demokrasi uygulamalarının başarı düzeyinin göstergesi olan uygulamalara bakıldığında toplumu oluşturan unsurlar olarak bireylerin örgütlü bir toplum yapısına sahiptir.

Türkiye ve İngiltere'nin karşılaştırılmasında göz önünde tutulan halk katılımı, idari yapı, mali yapı ve sosyokültürel unsurlar esasında ciddi bir demokrasi farkını da betimlemektedir. Türkiye'de halkın yönetimi etkileye bilmesinde seçimler etkiliyken İngiltere'de ise gerek duyulan dönemlerde yapılan bazı anketler bile belirleyici olmaktadır (Erdemir, 2010:79). Toplumda siyasi kültürün yerleşmiş olması katılım sürecinde önem taşımaktadır.

\section{SONUÇ}

Türkiye ve İngiltere'nin yerel demokrasi ve katılım boyutuyla karşılaştırıldığı bu çalışmada; Türkiye'nin İngiltere'ye göre yerel demokrasi ve katılım açısından oldukça geri planda olduğu görülmüştür. Türkiye'de günümüzde uygulanan 1980 Anayasası'nın 127. maddesi mahalli idarelere ayrılmış olup, bu bölümde aynı zamanda katılım olanağı olarak yalnızca yerel seçimlere yer verilmiştir. Yerel yönetimlere katılım konusundaki bu eksiklik yerel yönetim birimlerinin temelini oluşturan yasal düzenlemelerle giderilmeye çalışılmıştır. Özellikle 5393 sayılı Belediye Kanunu ile halkın yönetime katılımını sağlamak amacıyla çeşitli düzenlemeler getirilmiştir. Türkiye'de son yıllarda sınırlı da olsa yerel yönetimlerle ilgili düzenlemelerde sınırlı da olsa katılım mekanizmalarına yer verilmiştir. Ancak bu düzenlemeler ile gerçek anlamda yerel demokrasi ve katılım sağlanmamıştır.

İngiltere gibi Batı'da modern devletin oluşumunsa etkili olan merkezileşme süreci bir takım feodal temellere dayandığı için çevre güçlerle uzlaşma sonucunda ortaya çıkmıştır. Bu çevre güçlerden önde gelenlerden biri ise kentler (yerel yönetimler) olmaktadır. Burada önem taşıyan husus uzlaşma sürecinde çevre sistem içinde erimemiş, tam tersine özerklik elde etmiştir. Tarihsel süreçte bakıldığında ise Osmanlı'da bu durumun tam tersi yaşandığı, merkezle çevre arasında çatışmanın varlığı söz konusu olmuştur. Bu uzlaşmazlık günümüzde de 
ÖZER, Mehmet Akif ve KARTAL, Meryem - Yerel Demokrasi ve Katılım: Türkiye ve İngiltere Üzerinden Bir İnceleme

zaman zaman karşımıza çıkmaktadır. Türkiye'nin Osmanlı döneminden günümüze miras kalan siyasal kültür ve kurumlar yerel demokrasinin yeterince gelişmesinin önünde en büyük engellerden biri olmuştur.

Ülkemizde siyasi kültürün tam anlamıyla yerleşmemiş olması, demokrasinin yerleşmesinde temel aktörlerden biri olan sivil toplum anlayışının olmayışı, 2012 yılında çıkarılan 6360 Sayılı yasa ile büyükşehir olan illerde en önemli yerel yönetim birimleri olan köylerin ve il özel idarelerinin varlığına son verilmesi yer almaktadır. Bu kapsamda yerel demokrasi ve katılımın Türkiye'de geliştirilmesi gereken konulardan biri olduğu göz önünde bulundurulduğunda yerel temsil daha demokratik bir nitelikte olması ve yerel halkın daha fazla katılımını sağlayacak düzenlenmelerin yapılması gerekmektedir. Ayrıca son yıllarda reform başlığı altında yapılan düzenlemelere rağmen merkeziyetçi uygulamaların yerel yönetimler üzerinde ağırlığını hissettirmesi bu durumun altında yer alan temel etmendir.

İngiltere'nin küresel sistemdeki konumu, ekonomi, hukuk, vb. alanlarda dünyada önde gelen ülkelerden biridir. Bununla birlikte İngiltere, kamu yönetimi bir yandan geleneksel değerlerle olan bağlılı̆̆ını devam ettirirken diğer yandan modernizme ve güncel gelişmelere yönetsel alanda geniş yer veren bir ülkedir. 1980'li yıllardan beri devam eden yerelleşme ve reform süreçleri yönetim sistemine âdem-i merkeziyetçi bir nitelik kazandırırken aynı zamanda merkeziyetçilik geleneği de devam etmektedir. Üniter bir yapıya sahip olan ve yerinden yönetim ilkesinin iyi bir şekilde uygulanan İngiltere'de tarihsel gelişim süreci içinde yerel yönetimlere büyük önem verilmiştir. İçinde bulunduğumuz son yüzyılda İngiltere birçok yetki ve sorumluluğu yerel ve bölgesel düzeyde örgütlenen birimlerle paylaşmaktadır. Böylece merkeziyetçi yapının etkilerini en aza indirerek daha demokratik bir yapının oluşmasına yönelik çaba harcanmaktadır.

\section{KAYNAKÇA}

ARSLAN, Erkan (2018), “İniltere'de Yerelleşme Politikalarl ve Yerel Yönetimler”, İnsan ve Toplum Bilimleri Araştırmaları Dergisi, S.7(4), ss.2868-2884.

BEYAZYILDIZ, Osman (2010), "Türkiye'de Yerel Yönetimler ve Demokratikleşme Sürecine Etkisi”, Yayımlanmamış Yüksek Lisans Tezi, İstanbul Üniversitesi Sosyal Bilimler Enstitüsü, İstanbul.

BOZKURT, Yavuz (2014), "Yerel Demokrasi Aracı Olarak Türkiye’de Kent Konseyleri: Yapı, İşleyiş ve Sorunlar", Dumlupınar Üniversitesi Sosyal Bilimler Dergisi, S.40, ss.229-239.

BROWN, Mark B. (2006), "Survey Article: Citizen Panels and the Concept of Representation", The Journal of Political Philosophy, S.14(2), ss.203-225.

CANPOLAT, Hasan ve HAKTANKAÇMAZ, M. İlker (2010), "Yerel Yönetişim Sorunları Açısından Londra Büyükşehir Yönetimi”, Çağdaş Yerel Yönetimler Dergisi, S.19(1), ss.91-106.

CHANDLER, Jones (2015), Local Government Today, Manchester University Press, Manchester and New York.

COLE, Michael (2003), "Local Government Reform in Britain 1997-2001: National Forces and International Trends", Government and Opposition, S.38(2), ss.181-202.

COŞKUN, Bayram ve SEZER, Sergender (2004), "Yerel Yönetimler ve Katılım: Muğla Kent Meclisinin Örnek Olay Olarak Incelenmesi", Yerel Yönetimler Kongresi Bildiriler Kitabı, Çanakkale, ss.281-297.

ÇİFTÇİ, Oya (1999), “Yerel Siyaset ve Demokrasi, Çoğulculuk Sivil Toplum”, Sivil Toplum İçin Kent: Yerel Siyaset ve Demokrasi Seminerleri, Demokrasi Kitaplığı Yayını, Ankara, ss.233-249.

ÇOKER, Ziya (1970), Türk Mahalli İdarelerinin Sorunları Açısından İngiliz Mahalli İdareleri, Tetkik Kurulu Yayınları, Ankara.

ÇUKURÇAYIR, Mehmet Akif (2012), Siyasal Katılma ve Yerel Demokrasi, Çizgi Kitapevi Yayını, Konya.

EMREALP, Sadun (2005), Yerel Gündem 21 El Kitabı, IULA-EMME Yayını, İstanbul.

EMREALP, Sadun (2010), Türkiye’nin Katılımcı Demokratik Yerel Yönetişim Modeli Olarak Dünyaya Armağanı: Kent Konseyleri, UCLGMEWA Yayını, İstanbul.

ERBAY, Yusuf ve AKGÜN, Hasan (2017), Türkiye'de ve Avrupa'da Yerel Yönetimler, Akademik Yayınları, İstanbul. 
ERDEMIR, Tekin (2010), “Avrupa Birliği (AB) Uyum Sürecinde Türkiye ve İngiltere Yerel Yönetim Sistemlerinin Karşılaştırılmalı Analizi”, Yayımlanmamış Yüksek Lisans Tezi, Selçuk Üniversitesi Sosyal Bilimler Enstitüsü, Konya.

ERYILMAZ, Bilal (2002), "Belediyelerde Demokrasi Geleneği ve Değişim Ihtiyacı”, Çağdaş Yerel Yönetimler Dergisi, S.11(3), ss.6-20.

FISHKIN, James ve JOWELL, Roger (2000), “Deliberative Polling and Public Consultation”, Parliamentary Affairs, S.53(4), ss.657-666.

FRANDSEN, Annie (2002), "Size and Electoral Participation in Local Elections", Government and Policy Environment and Planning, S.20(6), ss.859-860.

FRIENDS OF THE EARTH (2008), "Beginners Guide to Local Authorities in England", E-Document, https://nanopdf.com/download/beginners-guide-to-local-authorities-in-england_pdf\#tab-share (Erişim Tarihi: 21.05.2020).

GODFREY, Caroline (2007), The Role of Parish Councils in Milton Keynes, Routledge Publishing, London. GÖRMEZ, Kemal (1997), Yerel Demokrasi ve Türkiye, Vadi Yayınları, Konya.

GÖRMEZ, Kemal ve UÇAR ALTINIŞIK, Harika (2011), "Yerel Demokrasi ve Kent Konseyleri", Kent Konseyleri Sempozyumu Bildiri Kitabı, 6-7 Mayis 2011, Bursa, ss.31-51.

GÜVEN, Ahmet ve ALAN, Çağatay (2019), "Türkiye'de Yerel Demokrasiyi Güçlendirme Aracı Olarak Yönetişim ve Yerel Yönetimlerde İşleyişi”, Hukuk ve İktisat Araştırmaları Dergisi, S.11(1), ss.47-61.

HAMAMCI, Can (1981), “Merkezi Yönetim Yerel Yönetim Ekseninde Belediyelerimizin Yapısı ve Demokratikleşme”, Yayımlanmamış Doktora Tezi, Ankara Üniversitesi Sosyal Bilimler Enstitüsü, Ankara.

HAMBLETON, Robin ve SWEETING, David (2004), "U.S. Style Leadership for English Local Government", Public Administration Review, S.64(4), ss.474-488.

HARRISON, Carolyn M., MUNTON, Richard J. ve COLLINS, Kevin (2004), "Experimental Discursive Spaces: Policy Processes, Public Participation and The Greater London Authority", Urban Studies, S.31(4), ss.903-917.

HEPER, Metin (1986), Dilemmas of Decentralization: Municipal Government in Turkey, Friedrich Ebert Foundation, Bonn.

HM TREASURY: CABINET OFFICE (2008), The Future Role of the Third Sector in Social and Economic Regeneration: Final Report, https://www.gov.uk/government/publications/the-future-role-of-the-thirdsector-in-social-and-economic-regeneration-final-report (Erişim Tarihi: 15.04.2020).

IMPROVEMENT AND DEVELOPMENT AGENCY (2008), "Consultation on the Equality Framework for Local Government”, Idea, http://www.idea.gov.uk/idk/aio/8493290 (Erişim Tarihi: 15.04.2020).

İBB - İSTANBUL BÜYÜKŞEHIR BELEDIYESİ (2010), Beyaz Masa Faaliyetleri Yıllık İstatistikleri, İstanbul Büyükşehir Belediyesi Yayını, İstanbul, http://www.ibb.gov.tr/tr TR/BilgiHizmetleri /Istatistikler/ Documents/beyazmasa/beyazmasa_faaliyetleri_2010_haziran.pdf (Erişim Tarihi: 03.08.2021).

KARASU, Koray (2013), “İngiltere'de Kamu Yönetimi”, Kamu Yönetimi Ülke İncelemeleri (Ed. Koray Karasu), İmge Kitabevi, Ankara, ss.145-292.

KAYACIOĞLU, Ersin ve SARIBAY, Ali Yaşar (1986), “Tanzimat: Modernleşme Arayışı ve Siyasal Değişme”, Türkiye'de Siyaset: Süreklilik ve Değiş̧im (Ed. Ersin Kayacıŏlu, Ali Yaşar Sarıbay), Der Yayınları, İstanbul, ss.9-38.

KEATING, Michael (1993), Reforging The Union: Devolution and Constitutional Change in The United, European University Institute Press, Florence.

KELEŞ, Ruşen (2014), Yerinden Yönetim ve Siyaset, Cem Yayınevi, İstanbul.

KOÇAK, Süleyman Yaman ve EKŞİ, Ali (2010), “Katılımcılık ve Demokrasi Perspektifinden Türkiye'de Yerel Yönetimler", Süleyman Demirel Üniversitesi Fen Edebiyat Fakültesi Sosyal Bilimler Dergisi, S.21, ss.295-307. 
ÖZER, Mehmet Akif ve KARTAL, Meryem - Yerel Demokrasi ve Katılım: Türkiye ve İngiltere Üzerinden Bir İnceleme

KOÇAK, Yüksel (2008), Karşılaştırmalı Yerel Yönetimler, Orion Kitabevi, Ankara.

KÖSECIK, Muhammed (2000), “Yerel Yönetim Teorileri ve Merkez Yerel Yönetim İlişkilerindeki Merkezileşme: Thatcher Dönemi”, Çağdaş Yerel Yönetimler Dergisi, S.9(1), ss.25-41.

MCDANIELS, Timothy (1996), "The Structured Value Referendum: Eliciting Preferences for Environmental Policy Alternatives", Journal of Policy Analysis and Management, S.15(2), ss.257-271.

MECEK, Mehmet (2017), “E-Devlet ve E-Belediye: Kavramsal Çerçeve ve Türkiye'de Belediye Web Sitelerine Yönelik Yapılan Çalışmaların Incelenmesi”, Süleyman Demirel Üniversitesi İ̈BF Dergisi, S.22(Kayfor15 Özel Say1s1), ss.1815-1851.

OKUTAN, Emre (2008), "Yerel Yönetimler ve Sivil Toplum Örgütlerinin Gelişmiş İşbirliği: İngiltere Örneği”, Sayıştay Dergisi, S.71, ss.91-108.

ORTAYLI, İlber (1974), Tanzimattan Sonra Mahalli İdareler, TODAİE Yayını, Ankara.

ORTAYLI, İlber (1985), Tanzimattan Cumhuriyete Yerel Yönetim Geleneği, Hil Yayıncılık, İstanbul.

ORTAYLI, İlber (2008), Türkiye Teşkilat ve İdare Tarihi, Cedit Neşriyat, Ankara.

ÖCAL, Süleyman (2001), “Ingiltere'de Yerel Yönetimler ve Thatcherizm”, Yüksek Lisans Tezi, Ankara Üniversitesi Sosyal Bilimler Enstitüsü, Ankara.

ÖNDER, Özgür (2013), "Yerelleşme ve Yerel Demokrasinin Güçlendirilmesi Bağlamında Yerel Katılım”, Uluslararası Yönetim İktisat ve İşletme Dergisi, S.9(18), ss.311-326.

ÖNEN, Nizam ve REYHAN, Cenk (2001), Mülkten Ülkeye, Türkiye'de Taşra İdaresinin Dönüşümü, İletişim Yayınları, İstanbul.

ÖNEZ, Zuhal (2006), "Local Agenda 21 and Participation to Local Administration: A Case Study in Denizli", Yayımlanmamış Yüksek Lisans Tezi, Orta Doğu Teknik Üniversitesi Sosyal Bilimler Enstitüsü, Ankara.

ÖZEL, Mehmet ve EREN, Veysel (2012), “Merkezi Yönetim ve Piyasa Kıskacındaki Yerel Yönetimler: Karşılaştırmalı Bir İnceleme”, International Journal of Human Sciences, S.9(2), ss.1379-1401.

ÖZER, Mehmet Akif (2013), "Yerel Yönetimler Reformunda Reform:6360 Sayılı Kanun'un Düşündürdükleri”, Yerel Politikalar Dergisi, S.(Ocak-Haziran), ss.98-126.

ÖZKAN, Ahmet (2015), “Amerika Birleşik Devletleri ve Ingiltere Örneğinde Yerel Özerklik”, Yayımlanmamış Yüksek Lisans Tezi, On dokuz Mayıs Üniversitesi Sosyal Bilimler Enstitüsü, Samsun.

PARLAK, Bekir ve ÖKMEN, Mustafa (2015), Yerel Yönetimler, Ekin Kitabevi, Bursa.

PEARCE, Graham ve ELLWOOD, Sheila (2002), Modernising Local Government: A Role for Parish and Town Councils, Routledge Publishing, London.

READ, Doanld (2014), The Age of Urban Democracy, Routladge, London.

RIPPE, Peter ve SCHABER, Peter (1999), “Democracy and Environmental Decision-Making”, Environmental Values, S.8(1), ss.75-88.

SABAHATTIN, Prens (1999), Türkiye Nasıl Kurtarılabilir? Ve İzahlar (Çev. İnan Keser), Liberte Yayınları, Ankara.

TORTOP, Nuri, AYKAÇ, Burhan, YAYMAN, Hüseyin ve ÖZER, Mehmet Akif (2006), Mahalli İdareler, Nobel Akademik Yayıncılık, Ankara.

USTA, Sefa, AKMAN, Elvalettin ve KOCAOĞLU, Mustafa (2017), "Yerelleşme-Merkezileşme Tartışmaları Ekseninde Yerel Yönetimlerde Reform: Ingiltere ve Türkiye Üzerine Mukayeseli Bir Analiz”, Selçuk Üniversitesi Sosyal Bilimler Meslek Yüksekokulu Dergisi, S.20(1), ss.68-78.

UYAR, Ahmet ve MECEK, Mehmet (2016), "Kent Bilincinin Oluşturulması ile Hizmet Pazarlaması Aracı Olarak Beyaz Masa Uygulaması ve Hukuki Yapısı: Afyonkarahisar Belediyesi Örneği”, Paradoks Ekonomi, Sosyoloji ve Politika Dergisi, S.11(Özel Say1), ss.143-157.

UYSAL, Birkan (1984), Siyasal Katılma ve Katılma Davranışına Ailenin Etkisi, TODAİE Yayını, Ankara. 
WOLLMANN, Helmut (2000), Local Government Systems: From Historic Divergence Towards Convergence? Great Britain, France, And Germany as Comparative Cases in Point, Berlin University Press, Berlin.

WOLLMANN, Helmut (2008), "Reforming Local Leadership and Local Democracy: The Cases of England, Sweden, Germany and France in Comparative Perspective", Local Government Studies, S.34(2), ss.279-298.

WORTHY, Benjamin, AMOS, Jim, HAZELL, Robert ve BOURKE, Gabrielle (2011), "Town Hall Transparency? The Impact of the Freedom of Information Act 2000 on Local Government in England", ESRC Economic \&Social Research Council, The Constitution Unit Department of Political Science University College Press, London.

YALÇINDAĞ, Selçuk (1996), Belediyelerimiz ve Halkla İlişsileri, TODAİE Yayını, Ankara.

YAMAÇ, Müzehher (2014), "Tarihsel Gelişim İçinde Üniter Bir Yapıda Yerel Yönetim: İngiltere Örneği”, Namık Kemal Universitesi Sosyal Bilimler Enstitüsü Dergisi, S.4, ss.1-23.

YAMAN, Murat ve KÜÇÜKŞEN, Murat (2018). "Yerel Yönetimlerin Demokratikleşmesi Açısından Yerel Katılımin İncelenmesi”, Dumlupınar Üniversitesi Sosyal Bilimler Dergisi, S.55, ss.247-259.

YAYLI, Hasan ve PUSTU, Yusuf (2008), “Yerel Demokrasinin Illkeleri”, Karadeniz Araştırmaları, S.16, ss.133-153.

YEREL YÖNETIMLER ÖZEL İHTISAS KOMISYONU RAPORU (2001), Sekizinci Beş Yıllık Kalkınma Planı, Devlet Planlama Teşkilatı Yayını, Ankara, https://www.sbb.gov.tr/ozel-ihtisas-komisyonuraporlari/ (Erişim Tarihi: 21.05.2021).

YILMAZ, Vedat (2019), "Doğu Anadolu Bölgesinde E-Belediyecilik Hizmetlerinin Yerel Halk Tarafindan Kullanım Düzeylerinin Değerlendirilmesi: Bittis ve Muş Belediyesi Örnekleri”, E-Yönetişim: Kavramsal/Kuramsal Çerçeve, Ülke İncelemeleri ve Türkiye'ye Yansımaları (Ed. Bekir Parlak, Kadir Caner Doğan), Beta Basım Yayım Dağıtım, İstanbul, ss.509-532.

YÜKSEL, Fatih (2005), “Yerel Özerklik Kavramı Üzerine Bir İnceleme”, Yerel Yönetimler Üzerine Güncel Yazılar I (Ed. Hüseyin Özgür, Muhammet Kösecik), Nobel Yayınları, Ankara, ss.275-296.

ZIMMERMAN, Joseph Francis (1999), The New England Town Meeting: Democracy in Action, Praeger Publisher, New York.

http://www.norfolkcitizenspanel.org/consumption/ (Erişim Tarihi: 21.05.2021).

http://www.sheffield.gov.uk/education/planspartnershipconsultation/consultation/abbeydalegrange

(Erişim

Tarihi: 21.05.2021).

https://www.aa.com.tr/tr/politika/secimlere-katilim-orani-etkileyiciydi/1439424 (Erişim Tarihi: 12.11.2019).

https://www.bankofengland.co.uk/quarterly-bulletin/2021/2021-q4/the-public-economist-learning-from-ourcitizens-panels-about-the-uk-economy (Erişim Tarihi: 21.05.2021).

https://www.gov.uk/government/organisations/independent-reconfiguration-panel/about (Erişim Tarihi: 18.12.2021).

https://www.legislation.gov.uk/ukdsi/2012/9780111517604/schedule/5 (Erişim Tarihi: 18.12.2021).

https://www.legislation.gov.uk/ukpga/Edw7/8/66/contents (Erişim Tarihi: 18.12.2021).

https://www.local.gov.uk/our-support/research-and-data/research-publications/residents-satisfaction-surveys (Erişim Tarihi: 15.10.2021).

https://www.newlocal.org.uk/articles/citizens-assemblies/ (Erişim Tarihi: 18.12.2021).

442 sayılı Köy Kanunu (07.04.1924 tarih ve 68 sayılı Resmi Gazete).

5302 sayı1ı İl Özel İdaresi Kanunu (04.03.2005 tarih ve 25745 say1lı Resmi Gazete).

5393 sayılı Belediye Kanunu (13.07.2005 tarih ve 25874 sayılı Resmi Gazete). 